
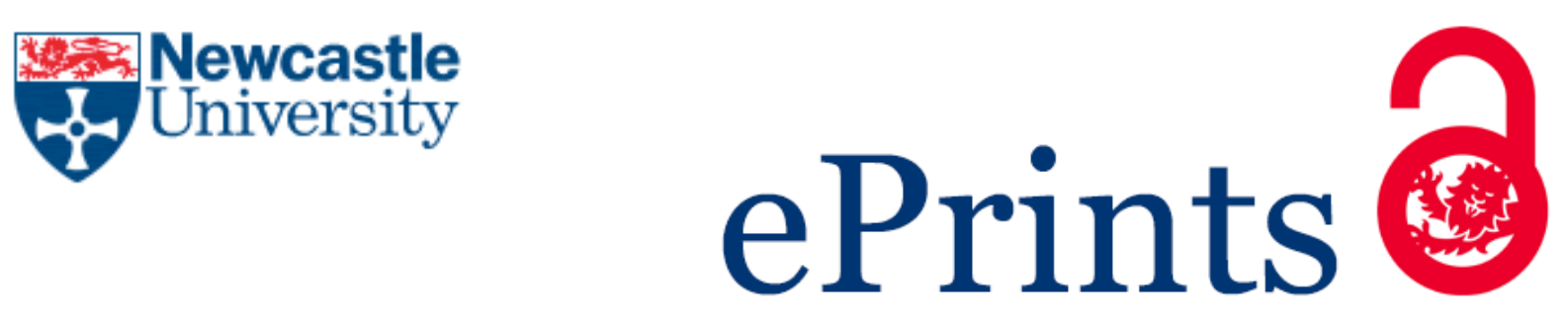

Su C.

The efficiency of IPO issuing mechanisms and market conditions: evidence in China.

Review of Quantitative Finance and Accounting 2017

DOI: https://doi.org/10.1007/s11156-017-0677-2

Copyright:

The final publication is available at Springer via https://doi.org/10.1007/s11156-017-0677-2

DOI link to article:

https://doi.org/10.1007/s11156-017-0677-2

Date deposited:

$18 / 10 / 2017$

Embargo release date:

17 October 2018

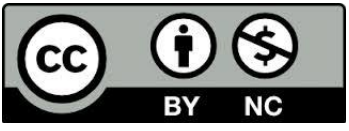

This work is licensed under a Creative Commons Attribution-NonCommercial 3.0 Unported License 


\title{
The efficiency of IPO issuing mechanisms and market conditions: Evidence in China*
}

\section{Chen Su}

Corresponding author.

Newcastle University Business School, 5 Barrack Road, Newcastle upon Tyne NE1 4SE, UK

Email: chen.su@ncl.ac.uk Tel: + 44 (0)1912081656Ｆax: + 44 (0) 1912081738

To cite this article: Chen Su (2017) The efficiency of IPO issuing mechanisms and market conditions: Evidence in China, Review of Quantitative Finance and Accounting, Forthcoming.

To link to this article: $\mathrm{DOI}: 10.1007 / \mathrm{s} 11156-017-0677-2$

(Received 30 January 2016, Accepted 03 October 2017, Available online 17 October 2017)

\begin{abstract}
This study conducts a comparison analysis on the efficiency of bookbuilding and secondary market proportional offering (hereafter, SMP offering) in the China stock market. SMP offering as described in this paper is not a follow-on offering, but an initial offering applicable to investors in the secondary market. Specifically, as a unique type of fixed price offering, SMP offering only allows the existing investors who are holding shares (of any listed firms) in the secondary market to subscribe to IPO shares. The amount of IPO shares available to be subscribed by the existing investors is proportional to market value of shares held by them in the secondary market. We find some interesting evidence showing that, compared with bookbuilding, SMP offering is more efficient for pricing IPOs, particularly, in a volatile market. SMP offering leads to lower underpricing and lower cross-sectional variation of short-run returns of IPOs. Also, SMP offering is better able to counteract adverse market conditions in the form of low market return and/or high market volatility. Our results are robust to various alternative tests, e.g., the Heckman (1979) twostage procedure and an out-of-sample test, after controlling for the problem of endogeneity and for the influence of the exchange of listing, respectively.
\end{abstract}

Keywords: IPO issuing mechanism; underpricing; market conditions; bookbuilding; secondary market proportional offering (SMP offering)

JEL Classification: G15, G24, G32

\footnotetext{
* Acknowledgements: The author wishes to thank the editor (Cheng-Few Lee) and an anonymous reviewer for their constructive comments and suggestions that help significantly improve this paper. The author is also grateful to Carol O. Alexander, David Brookfield, Bartosz T. Gebka, Simon Hussain, Brian M. Lucey, and Christian C.P. Wolff for their helpful advice and comments on earlier drafts of this paper. This work was financially supported by Newcastle University Business School under the School Pump Priming/Research Fund 2013/14 (OSR/0372/SPPF/0009). All errors are my own.
} 
Introduction

A substantial body of evidence indicates that there is a tendency for initial public offerings (IPOs) to appear underpriced on the first day of trading (see recent reviews in Ritter and Welch 2002; Ritter 2003; Ljungqvist 2007). ${ }^{1}$ It has been widely argued that a deeper understanding of the role of issuing mechanisms might help inform aspects of the unsolved puzzle of IPO underpricing. An appropriate choice and deployment of issuing mechanisms might ameliorate the impact of information asymmetry between issuers and investors (Neupane and Poshakwale 2012). Ritter (2002) summarizes three principal types of globally employed issuing mechanisms: auction, bookbuilding, and fixed price offerings, which differ mainly in price discovery and share allocation process. The seminal study of Benveniste and Spindt (1989) argues that bookbuilding can lead to more efficient price discovery as it allows underwriters to determine at what price to offer an IPO based on the demand from institutional investors. Numerous subsequent studies show that bookbuilding is associated with a lower level of IPO underpricing (see Benveniste and Wihelm 1990; Sherman 2000). Although bookbuilding is becoming increasingly dominant worldwide and estimated to account for over $80 \%$ of IPOs outside the US and Canada (Ljungqvist et al. 2003), international evidence on the efficiency of bookbuilding is rather mixed, showing that the choice of issuing mechanisms and the level of underpricing vary across markets. For example, in contrast to the conventional viewpoint, Busaba and Chang (2010) argue that, on average, fixed price offering produces higher expected proceeds, unless the underwriter can target its bookbuilding to a small subset of informed investors. Ljungqvist et al. (2003) empirically examine a sample of 2,143 IPOs in 65 stock markets outside the US in the 1990s. They report an average underpricing of around $20 \%$ for fixed price offerings (close to that for IPOs using bookbuilding), implying that fixed price offering still remains an efficient, low cost way to distribute IPO shares. Degeorge et al. (2010) also suggest that auction can be an effective alternative to traditional bookbuilding. ${ }^{2}$

In contributing to this debate, this study sheds additional light on the efficiency of issuing mechanisms for pricing IPOs in the China stock market, which has experienced tremendous development in IPO activities in the last two decades. Our particular attention on the China stock market is motivated by the following considerations. First, there exist several basic and substantially different issuing mechanisms in the China stock market, such as auction, bookbuilding, and various types of fixed price offering, including online fixed price offering, secondary market proportional offering (hereafter, SMP offering), and bookbuilding plus SMP offering, etc. The China stock market, therefore, offers an ideal arena to address the challenging question of which issuing mechanism is more efficient for pricing IPOs in a single-country context. In particular, SMP offering as described in this paper is not a follow-on offering (or a dilutive

\footnotetext{
${ }^{1}$ A routinely updated Table 1 in Loughran et al. (1994) presents comprehensive evidence on the level of IPO underpricing worldwide (Available at: https://site.warrington.ufl.edu/ritter/files/2017/05/IPOs2016Underpricing.pdf).

${ }^{2}$ Jagannathan et al. (2015) conduct a comparative review of the three most common types of IPO issuing mechanisms in 47 international markets and provide potential explanations on why auction is unpopular in most markets. We note, but do not explore, the existence of numerous studies on the efficiency of auction-related issuing mechanisms (see Biais and Faugeron-Crouzet 2002; Derrien and Womack 2003; Sherman 2005; Lowry et al. 2010).
} 
secondary offering), ${ }^{3}$ but an initial offering applicable to investors in the secondary market. The distinguishing feature of SMP offering is that it only allows the existing investors who are holding shares (of any listed firms) in the secondary market to subscribe to IPO shares. The right to buy IPO shares depends on whether investors are holding shares in the secondary market, while the amount of IPO shares available to be subscribed by the existing investors is proportional to market value of shares held by them.

Furthermore, although the China stock market has become one of the largest and most important emerging markets in the world, its institutional settings and trading practices are relatively new and, in part, different from and independent of those in developed markets. For example, the dominance of individual investors, the existence of a majority of non-tradable shares (or the split-share structure), and the long gap between the offering and listing dates for IPOs have been extensively criticized as an indicator of bureaucratic control, operating inefficiency, and severe information asymmetry (Chan et al. 2004). As a result, it takes longer for any information to be fully reflected in asset prices, which can cause the role of issuing mechanisms in emerging markets to be distinct from that in developed markets.

As a transitional institutional setting, SMP offering was built on the existence of the split-share structure in the China stock market. The primary purpose of the implementation of SMP offering is to reduce the IPO subscription costs for investors in the secondary market. With the formal launch of the splitshare structure reform in 2005, non-tradable shares were gradually converted into tradable shares and the foundation of SMP offering no longer existed (see details on related institutional background in Subsection 2.1). Accordingly, a milestone document-Circular on Several Issues Concerning on the Trial Implementation of an Inquiry System for Initial Public Offering of Shares (No. 162 [2004]; hereafter, The Regulation 2004) - was issued by the China Securities Regulatory Committee (CSRC) on December 7th, 2004 and effective as of January 1st, 2005, marking the establishment of a market-oriented issuing mechanism (bookbuilding) to increase the efficiency for marketing and pricing IPOs in the China stock market. Such institutional reform, however, may make previous empirical models inadequate to effectively explain IPO pricing behavior in the China stock market, without taking the role of issuing mechanisms into account.

Indeed, although the severe level of IPO underpricing in the China stock market has been well reported (see Mok and Hui 1998; Chan et al. 2004), previous studies pay little attention to the explanatory power of issuing mechanisms. Yong (2007) conducts a comprehensive review of research on Asian IPOs and points out that this research area is still lacking and worth looking into. A recent study of Ma and Faff (2007) examines an early sample of 942 Chinese IPOs issued over the period 1994 to 2003 and supports the idea that bookbuilding increases pricing accuracy and is optimal in counteracting adverse market conditions. However, given the chosen sample period, they compare a very limited sample of 51 IPOs using bookbuilding with 891 fixed price offerings, making their empirical results somewhat unrepresentative.

\footnotetext{
${ }^{3}$ In a follow-on offering, the listed firm itself issues additional shares on the primary market after the initial offering, thus diluting the existing shares.
} 
Guo and Brooks (2008) also account for various issuing mechanisms in the China stock market before 2005, but their sample does not include any IPOs using bookbuiding.

This study comparatively examines the efficiency of various issuing mechanisms using a more recent sample of 523 IPOs in the China stock market over the period April 2001 to September 2008. We also include an out-of-sample of 90 IPOs issued over the period July 2009 to October 2012 for robustness analysis. To the best of our knowledge, this is the first study focusing on a comparison of the efficiency of bookbuilding and SMP offering (a dominant fixed price offering) in the China stock market. The primary objective of this study is to test two criteria proposed by Derrien and Womack (2003) for assessing the efficiency of IPO issuing mechanisms. That is, an efficient issuing mechanism is able to (i) lead to lower underpricing and lower cross-sectional variation of initial returns, and (ii) counteract adverse market conditions in the form of low market return and/or high market volatility. This study provides some interesting evidence to complement the existing finance literature, and has important relevance to market participants and financial regulators.

First, we find a mean market-adjusted initial return of $95.16 \%$ for IPOs over the period 2001 to 2005 , which is relatively lower than the well-known severe level of underpricing during the 1990s. For example, Zhou and Zhou (2010) examine 1,380 A-share IPOs over the period 1991 to 2005 and report an average underpricing of 238\% (see also Mok and Hui 1998; Chan et al. 2004). However, the comparatively modest level of IPO underpricing observed from 2001 to 2005 does not persist in the subsequent period, as we find a mean market-adjusted initial return of $146.84 \%$ over the period 2006 to 2008 that reaches $202.50 \%$ in 2007. We conjecture that the rebound of the substantial IPO underpricing after 2005 could be due to the change in market conditions. A formal test confirms that market conditions in terms of market return and volatility have significantly positive impacts on the level of IPO underpricing.

In addition, market practitioners generally suggest that the typical aim of underwriters is not only to underprice, but to control aftermarket price variations, especially on the downside (Derrien and Womack 2003). Inferring from this, we would expect that an efficient issuing mechanism is reflected in both lower underpricing and lower variance proxied by the cross-sectional squared deviations of IPO underpricing. We are not aware of any previous study that examines the impact of market conditions on the variance of IPO underpricing in an emerging market context. We find that market conditions in terms of market return and volatility have significantly positive impacts on the variance of short-run returns of IPOs.

Finally, the most important finding of this study is that, compared with bookbuilding, SMP offering is associated with greater efficiency for pricing IPOs, in particular, in the face of adverse market return and volatility. It could be due to the fact that SMP offering makes the secondary market existing investors as signal conduits because of their experience of firm performance in different market conditions. These experienced investors have phenomenal knowledge of share ownership of issuers in the stock market and are better able to deal with noisy signals; this is not necessarily the case for bookbuilding. In this way, the behavior of these secondary market existing investors could be intentionally followed by less-informed investors in making decisions concerning potential IPO investment. Therefore, the quality of signals is 
better in SMP offering (see more discussions in Subsection 2.2). Our results are robust to various alternative tests, e.g., the Heckman (1979) two-stage procedure and an out-of-sample test, after controlling for the problem of endogeneity and for the influence of the exchange of listing, respectively.

The remainder of this paper is organized as follows. The following section introduces relevant institutional background in the China stock market and develops hypotheses. Section 3 describes data and sample statistics, while Section 4 presents empirical results, followed by various robustness tests in Section 5. The final section concludes this paper.

\section{Institutional background and hypothesis development}

\subsection{Institutional background}

IPO issuing mechanisms in the China stock market have undergone significant changes since the early 1990s. Before the Shanghai Stock Exchange (SHSE) was inaugurated in December 1990 and the Shenzhen Stock Exchange (SZSE) was opened in April 1991, a number of firms issued IPO shares by private placement to employees and local public, without the participation of underwriters. With the establishment of both stock exchanges, IPO issuing mechanisms were characterized by the limited subscription warrants, which were soon replaced by the unlimited subscription warrants in 1992 .

Since 1994, several types of fixed price offering have become increasingly popular, such as online fixed price offering, SMP offering, as well as online fixed price plus SMP offering, etc. For example, online fixed price offering sets a fixed offering price and allocates IPO shares using the lottery drawing through an electronic trading system. ${ }^{4}$ In contrast, SMP offering requires IPO shares to be sold to subscribers who have already held shares in the secondary market with a proportion on the basis of market value of shares held by these investors. That is, SMP offering only allows the existing investors who hold shares in the secondary market to subscribe to IPO shares; the amount of IPO shares available to the existing investors is proportional to market value of shares held by them in the secondary market.

An innovated SMP offering allocates IPO shares to existing individual investors proportionally to market value of their shares in the secondary market through an electronic trading system, and to institutional investors proportionally to their subscriptions over the counter. To direct more investors to the secondary market, the CSRC published Circular on Relevant Issues Concerning the Issue of New Shares to Investors in the Secondary Market (No. 5 [2000]) on February 13th, 2000, allowing half of IPO shares to be allocated to the existing secondary market investors. In 2000, 35 IPOs adopted this issuing mechanism until it ceased operation after 2000 because of technical problems. On May 20th, 2002, the CSRC published Supplementary Circular on Relevant Issues Concerning the Issue of New Shares to Investors in the

\footnotetext{
${ }^{4}$ As required by the CSRC, the offering price is based on the price-to-earnings (P/E) ratio and the forecasted earnings per share (EPS): the offering price $=P / E \times$ the forecasted $E P S$, where the $\mathrm{P} / \mathrm{E}$ ratio was initially fixed at 15 . There were substantial changes in the measurements of EPS. For example, on December 26th, 1996, the CSRC changed the measurement of EPS based on the realized arithmetic average EPS in the past three years: $E P S_{t}=\left(\right.$ the realized $E P S_{t-3}+$ the realized $E P S_{t-2}+$ the realized $\left.E P S_{t-1}\right) / 3$. The CSRC adjusted the measurement of EPS again on September 10th, 1997, based on the weighted average of the realized EPS in the year before the IPO and the forecasted EPS during the IPO year: $E P S_{t}=0.7 \times$ the realized $E P S_{t-1}+0.3 \times$ the forecasted EPS . On March 17th, 1998, the CSRC again changed the measurement of EPS back to the forecasted EPS: EPS = forecasted earnings/[the total number of shares before IPO + the number of IPO shares $\times(12-M) / 12]$, where $M$ is the month when the IPO is issued.
} 
Secondary Market (No. 54 [2002]) to resume SMP offering and adjusted the percentage of IPO shares that could be allocated to the secondary market existing investors from $50 \%$ to $100 \%$.

As a transitional institutional setting, SMP offering was built on the existence of the split-share structure in the China stock market, ${ }^{5}$ in attempts to reduce the IPO subscription costs for investors in the secondary market. However, with the formal launch of the split-share structure reform in $2005,{ }^{6}$ nontradable shares were gradually converted into tradable shares; the foundation of SMP offering thus no longer existed. With the release of Circular on Further Improving Methods of Issuing Shares (No. 94 [1999]) by the CSRC on July 28th, 1999, bookbuilding was first introduced to the China stock market, allowing issuers and leading underwriters to set an initial offering price range and to determine the final offering price after a series of consultations with institutional investors. The final offering price is still subject to approval from the CSRC, especially if the recommended price is not within the suggested range of the P/E ratio. $^{7}$ Although the experimental bookbuilding was only applied to issuers with the IPO size of more than RMB 400 million, this was a signal that the China stock market made strides towards a market-oriented issuing mechanism to increase the efficiency for marketing and pricing IPOs. A total of 31 IPOs (3 in 1999 and 28 in 2000) employed bookbuilding before it was suspended in late 2000. Since its restoration on November 6th, 2001, bookbuilding was generally employed by IPOs issued in 2001 and in the first five months of 2002 until the CSRC required issuers to allocate IPO shares to the secondary market existing investors in May 2002.

Despite the frequent changes in IPO issuing mechanisms, ${ }^{8}$ fixed price offering predominated the China stock market until The Regulation 2004 was implemented on January 1st, 2005, along with its accompanying document-Memorandum No. 18 of Approval Standards on Share Issuance: Regulatory

\footnotetext{
${ }^{5}$ The ownership structure of firms listed in the China stock market has some unique features. For example, most listed firms are state-owned enterprises (SOEs) and a majority of shares are non-tradable shares, owned by the government and/or other legal entities. Specifically, the ordinary shares of a typical listed firm in the China stock market can be classified into two categories: tradable shares and non-tradable shares, which is also referred to as the split-share structure. Tradable shares include A-shares and B-shares traded either on the SHSE or on the SZSE, while non-tradable shares include: (i) state-owned shares held by state authorized investment departments or institutions with state assets; (ii) state-owned legal person shares held by other state-owned enterprises; (iii) legal person shares held by corporate enterprises or public institutions and social bodies; and (iv) employee shares held by employees and initially prohibited from trading for a certain time period until they become tradable.

${ }^{6}$ The CSRC released Circular on Issues Relating to the Pilot Reform of Listed Companies Split Share on April 29, 2005 (No. 32 [2005]), marking the launch of the first phase of its split-share structure reform by inviting four listed firms to convert their nontradable shares into tradable shares. On September 5, 2005, the CSRC issued the first official document-Administrative Measures on the Split Share Structure Reform of Listed Companies (No. 86 [2005]), providing guidelines on the implementation of the splitshare structure reform.

${ }^{7}$ As the China stock market was at an early development stage, neither institutional nor individual investors were able to determine the value of an issuer, resulting in some overheated IPOs with very high offering P/E ratios in 2000. For example, Fujian Mindong Electric Power Co., Ltd. (000993) went public on the SZSE with a record high P/E ratio of 88.69 on July 31st, 2000. To cool down the overheated IPOs with excessively high P/E ratios, on July 1st, 2001, the CSRC introduced an upper limit on the P/E ratio of 20 , which was lifted in 2005, though, in practice, the CSRC did not approve IPOs with a P/E ratio of greater than 30.

${ }^{8}$ Several experimental auction mechanisms were implemented in 1994 and 1995. Specifically, issuers and underwriters set an initial price and investors were required to bid for both price and quantity. The final offering price was set at the level where the accumulative quantities demanded by investors were equal to the total number of new shares available. However, only four IPOs issued between June 1994 and January 1995 employed this auction mechanism. Furthermore, two pro rata mechanisms were introduced by the CSRC on December 16th, 1996. Investors were required to save enough money to subscribe to IPO shares in special accounts, and IPO shares were allocated pro rata in case of over-subscription. The two pro rata mechanisms were widely adopted in 1996 and 1997, but were never used after 1998. A summary description of relevant issuing mechanisms employed in the China stock market over the period from 1994 to 2003 is presented in Ma and Faff (2007).
} 
Requirements Applicable to Institutions Participating in the Bookbuilding Process. An updated bookbuilding was designed by the CRSC to attract more institutional investors to the pricing process. Specifically, bookbuilding contains a preliminary inquiry session and a following cumulative bidding inquiry session, or road show session. The issuer and its nominated advisor (usually its leading underwriter) first file for registration with the CSRC and then hand in the due diligence report. Once the registration is approved by the CSRC, the report is delivered to a number of qualified institutional investors (no less than 20 selected by the underwriter) who participate in the preliminary inquiry session to conduct the price consultation until the offering price range is settled. The leading underwriter then organizes the road show campaigns, accumulates bid volumes from all qualified institutional investors within the offering price range, sets the offering price according to market demands, and finally allocates IPO shares according to the bid size. The qualified institutional investors include securities investment and fund management firms, securities firms, trust and investment firms, financial firms, insurance institutional investors, qualified foreign institutional investors (QFII), and other institutional investors approved by the CSRC.

On September 11th, 2006, the CSRC published Administrative Measures on Securities Issuance and Underwriting (No. 37 [2006]; hereafter The Measure 2006), stipulating that IPO shares could be allocated to strategic investors if the IPO size is RMB 400 million or more; strategic investors must hold these shares for at least 12 months as committed. Also, the number of IPO shares allocated to qualified institutional investors should not exceed $20 \%$ of the total IPO size if the IPO size is less than RMB 400 million, while the number of IPO shares allocated to qualified institutional investors should not exceed $50 \%$ of the total IPO size if the IPO size is RMB 400 million or more; the qualified institutional investors must hold these shares for at least three months as committed.

In order to further enhance the efficiency of the bookbuilding process, the CSRC formulated Guidance on Further Reforming and Improving New Issue Process (No. 13 [2009]) on June 10th, 2009, providing leading underwriters with complete freedom to determine the offering price. For example, an elimination system was introduced in the preliminary inquiry session, that is, investors who fail to make valid bids in the preliminary inquiry session are not eligible to participate in the following cumulative bidding inquiry session. In addition, institutions that have made valid bids in the preliminary inquiry session have to participate in the following cumulative bidding inquiry session and complete subscriptions, preventing those investors from making overpriced subscriptions but then default. Furthermore, the total subscription volumes made in the cumulative bidding inquiry session must be no less than those planned in the preliminary inquiry session. Since then, the preliminary price inquiry has become a key element in the bookbuilding process, marking the establishment of a more market-oriented issuing mechanism in the China stock market (see Deng and Zhou 2016).

In accordance with the unified arrangements on reforming IPO issuing mechanism, the CSRC formulated Guidance on Further Reforming New Share Issuance (No. 26 [2010]) on October 11th, 2010, allowing both institutional and experienced individual investors to participate in the preliminary inquiry session and subsequent share allocation process. Also, the CSRC made a series of amendments on The 
Measure 2006 (see e.g. No. 69 [2010 Revision] on October 11th, 2010; No. 78 [2012 Revision] on May 18th, 2012; No. 95 [2013 Revision] on December 13th, 2013; No. 98 [2014 Revision] on March 21st, 2014; No. 121 [2015 Revision] on December 30th, 2015). For example, the three-month holding period for qualified institutional investors was abolished. Instead, issuers, leading underwriters, and institutional investors may agree on a minimum holding period of IPO shares on their own. After prospectuses are published, issuers and leading underwriters may communicate with certain institutions non-publicly and learn about their pricing intentions, to make predictions about the offering price range; other legal and feasible approaches may also be employed. Issuers and leading underwriters may directly set the final offering price according to the consultations in the preliminary inquiry session; alternatively, they may set the offering price range through the preliminary inquiry session and then determine the final offering price (within the offering price range) in the cumulative bidding inquiry session.

\subsection{Hypothesis development}

Theoretical work in explaining IPO underpricing always assumes that market participants are rational and the objective of issuers is to maximize the funds raised in a given market condition and market structure in the knowledge that there exist heterogeneous investor groups (see Biais and Faugeron-Crouzet 2002; Ritter and Welch 2002; Kennedy et al. 2006; Ljungqvist et al. 2006). As noted by Sherman and Titman (2002), information asymmetry has a substantial impact on the accuracy of the IPO pricing process. Specifically, it should be more difficult to estimate accurately the value of an issuer in a volatile market, which gives rise to the potential emergence of more severe information asymmetry. ${ }^{9}$ Rock (1986) predicts that, on average, issuers characterized by more severe information asymmetry tend to be more underpriced, a prediction that has received considerable empirical support (see Kennedy et al. 2006).

Bookbuilding is a systematic process by which an underwriter (investment bank) appointed by the issuer attempts to determine the offering price of an IPO based on the demand from institutional investors. The traditional viewpoint generally argues that bookbuilding can lead to more efficient price discovery and less severe information asymmetry, due to its advantage in information collection and the full discretion of share allocation by underwriters (see Benveniste and Spindt 1989; Benveniste and Wihelm 1990; Sherman 2000). It is expected that underwriters, as financial intermediaries in the new issue market, play an important role as information producers to reduce information asymmetry surrounding issuers. However, some evidence from regulatory settlements and the financial press highlights the difficulty of underwriters in accurately pricing IPOs during the share allocation process. For example, during the road show session, the process of promoting an IPO firm to institutional investors fails to resolve much of the uncertainty in the market, probably because underwriters have allocated more underpriced IPOs to institutional investors who can pay large brokerage commissions (see Binay et al. 2007). Moreover, Krigman et al. (2001) and Houston et al. (2006) argue that price discovery is not the only service provided by underwriters, and accurate price discovery may not always be their primary objective. In fact, underwriters make more efforts in the

\footnotetext{
${ }^{9}$ Lowry et al. (2010) argue that, in a volatile market, a higher level of underpricing is expected to compensate investors for their greater costs of becoming informed and a higher variance of initial returns is expected because it is difficult for investors to estimate the value of the issuer.
} 
provision of auxiliary services, such as price support, market making, and analyst coverage, etc., rather than striving to minimize pricing errors in the IPO process. Many issuers thus place a very high value on underwriters' ability in order to guarantee certain post-IPO services. This might explain the dominance of bookbuilding worldwide despite its lack of accurate price discovery (see Ljungqvist et al. 2003; Lowry et al. 2010).

In addition, the available evidence casts doubts on bookbuilding as an efficient issuing mechanism of conveying public information, that is, public information seems not be fully incorporated into the offering price when the role of heterogeneous investor groups is recognized and information asymmetry emerges (see Bradley and Jordan 2002; Loughran and Ritter 2002; Lowry and Schwert 2004). In particular, when the market is volatile and signals are noisy, then the impact of information flows on different investor groups becomes blurred, we could expect the IPO price distribution to be wider and underpricing to grow faster than that observed under a benign market condition (Beatty and Ritter 1986). In this type of situation, the price-based market mechanism cannot ex ante fully resolve uncertainty relating even to public information; investors naturally then look to non-price information signals and one approach is for lessinformed investors to rely more heavily on the purchasing action of informed investors. ${ }^{10}$ This is a type of information cascades in which investors infer relevant information from the observed behavior of those presumed to hold superior information in the market (Ritter and Welch 2002).

It is in this context that SMP offering has an advantage in a more efficient manner, because SMP offering targets an investment community - the existing investors who are holding shares in the secondary market. Specifically, SMP offering requires IPO shares to be sold only to investors who have already held shares (of any listed firm) in the secondary market. SMP offering makes these existing investors in the secondary market as signal conduits, as they have plenty of experience of firm performance in the stock market from their ownership of shares over a period of time, and thus are better able to deal with noisy signals and discern how issuers will perform in different market conditions; this is not necessarily the case for bookbuilding. In this way, less-informed investors ignore their own noisy information and intentionally follow the observed behavior of secondary market existing investors in making decisions concerning potential IPO investment. Therefore, SMP offering is expected to more effectively reduce the level of information asymmetry and potentially contribute to more accurate price discovery.

Derrien and Womack (2003) argue that underwriters aim not only to underprice, but also to control aftermarket price variations. Lowry et al. (2010) propose a new metric for evaluating the pricing of IPOs-the volatility of initial returns, which is positively related to the level of underpricing. Inferring from this argument and according to the above discussions, we test the following two main hypotheses:

\footnotetext{
${ }^{10}$ Loughran et al. (1994) argue that, under information asymmetry, the existing shareholders and managers have information advantages over prospective investors in regard to the issuer, as prospective investors rely primarily on financial statements in the prospectuses, which are supposed to be presented in a favorable manner. That is, issuers might boost earnings relative to cash flows before the IPO and the profitability declines after the IPO. Therefore, prospective investors cannot effectively identify the quality of issuers, leading to an adverse selection problem, and eventually a lemon market (Beatty and Ritter 1986; Rock 1986; Balvers et al. 1993; Mantell 2016).
} 
H1: Compared with bookbuilding, SMP offering is more capable of leading to lower underpricing and lower cross-sectional variation of initial returns;

H2: Compared with bookbuilding, SMP offering is more capable of counteracting adverse market conditions in the form of low market return and/or high market volatility.

\subsection{Data and sample selection}

This study examines 523 Chinese IPOs over the period April 2001 to September 2008: 256 on the SHSE and 267 on the SZSE, covering 94.06\% of all IPOs issued during the approval system period, which replaced the old quota system for selecting IPOs. ${ }^{11}$ We also include an out-of-sample of 90 IPOs issued over the period July 2009 to October 2012 for robustness analysis (see Subsection 5.2). This sample period is chosen because of two long-term IPO suspensions in the China stock market from September 2008 to July 2009 and from November 2012 to December 2013. All financial firms are excluded due to their highly regulated nature, according to the two-digit Industry Classification Benchmark (ICB) codes 83-87. Data on the offering price, first trading day closing price, gross proceeds, number of tradable shares, and total shares outstanding of each IPO firm are collected from the China Stock Market \& Accounting Research (CSMAR) database via Wharton Research Data Services (WRDS). We also use official websites of the SHSE (http://www.sse.com.cn) and SZSE (http://www.szse.cn) as well as prospectuses to double-check data accuracy for each IPO candidate.

\subsection{Descriptive statistics}

Table 1 summarizes the distribution of 523 Chinese IPOs by the year of issuing from 2001 to 2008, in terms of the number of IPOs, market-adjusted initial return, and aggregate gross proceeds. The market-adjusted initial return of each IPO on the SHSE or SZSE is measured by the percentage difference between the first trading day closing price and offering price, relative to the contemporaneous return on the SHSE or SZSE A-Share Index, respectively. Table 1 shows a mean market-adjusted initial return of $95.16 \%$ over the period 2001 to 2005, which is much lower than the well-documented extremely high level of IPO underpricing during the 1990s. For example, Mok and Hui (1998) find that 87 IPOs on the SHSE record an underpricing of $289.2 \%$ from 1990 to 1993 , while Chan et al. (2004) report an underpricing of $177.8 \%$ of 570 A-share IPOs from 1993 to 1998 . However, the relatively modest level of underpricing observed from 2001 to 2005 does not persist in the subsequent period, as we find an average level of underpricing of $146.84 \%$ over the period 2006 to 2008 reaching $202.50 \%$ in 2007. One possible reason for the recurrence of substantial underpricing after 2005 is indicated in Figure 1, which illustrates a close relationship between the level of

\footnotetext{
${ }^{11}$ Under the old quota system, the quantity of IPOs to be issued each year was determined by the central government and then allocated among regional governments and ministries. The CSRC, the regulatory authority of the China securities market acting on behalf of the central government (rather than underwriters) was in charge of pricing and timing of IPOs. As a response to the extreme government intervention and to promote a more market-oriented and internationalized IPO allocation system, the quota system was replaced by an approval system in April 2001. Since then, underwriters have been taking more responsibility to evaluate issuers' credit standing as well as risk, and been able to recommend qualified firms to the CSRC for the final verification as long as the recommended firms meet all relevant standards and requirements (see Su 2015). Therefore, in order to ensure more accurate estimation, this study confines the sample to IPOs issued exclusively during the approval system period as this helps reduce the possibility that other factors, such as the changing role of underwriters, might affect our results.
} 
IPO underpricing and market performance. Specifically, the China stock market maintained a long-term downward trend from 2001 to 2005, and then experienced a dramatic rebound from 2006 to 2007 thwarted by the 2008 global financial crisis. Figure 2 clearly shows that the variance of initial returns is positively related to the level of IPO underpricing, consistent with the prediction of Rock (1986) that, on average, the issuers characterized by more severe information asymmetry tend to be more underpriced.

\section{<Table 1>}

\section{$<$ Figures 1 \& 2>}

Table 1 also shows a three-year suspension of IPOs on the SZSE from 2001 to 2003 before the launch of the Small and Medium Enterprises (SMEs) Board on the SZSE in June 2004. ${ }^{12}$ Compared with the Main Board, the SMEs Board has a more customized system with relatively lower entry requirements, providing a convenient financing platform for SMEs in the high-tech industry sector. From 2004 to 2008, $75 \%$ of IPO candidates (267 out of 356) went public on the SMEs Board, so it is not surprising that the average gross proceeds of RMB 316.78 million raised by IPOs on the SZSE are significantly smaller than those of RMB $1,720.95$ million raised on the SHSE at the $1 \%$ level $\left(t\right.$-stat $=3.60$; Kruskal-Wallis $\left.\chi^{2}=16.92\right) .{ }^{13}$ The gross proceeds are adjusted using the Consumer Price Index (CPI; $2005=100)$, obtained from the China Statistical Database of National Bureau of Statistics (NBS). In addition, the mean market-adjusted initial return of IPOs on the SHSE is $100.80 \%$, which is significantly lower than that of IPOs on the SZSE, $137.37 \%$, at the $1 \%$ level $\left(t\right.$-stat $=4.59$; Kruskal-Wallis $\left.\chi^{2}=14.83\right)$, implying a negative relationship between the IPO size and the level of underpricing.

\section{$<$ Table 2>}

Table 2 summarizes descriptive statistics for IPOs across various issuing mechanisms: bookbuilding (BB); online fixed price offering (OFP); SMP offering (SMP); and bookbuilding plus SMP offering (BS). The numbers of BB or SMP offerings are comparable (271 for BB versus 208 for SMP), while there are much fewer BS or OFP offerings in our sample (26 for OFP; 18 for BS). Table 2 also shows that BB and OFP offerings have considerably higher mean $(\mu)$ and variance $(\sigma)$ of initial returns $(\mu=145.08 \%$ and $\sigma=$ $102.30 \%$ for BB; $\mu=149.61 \%$ and $\sigma=100.00 \%$ for OFP), compared with BS and SMP offerings ( $\mu=$ $88.11 \%$ and $\sigma=69.98 \%$ for BS; $\mu=85.04 \%$ and $\sigma=62.98 \%$ for SMP). This thus raises concerns on the role of underwriters in price discovery and casts doubts on bookbuilding as an efficient issuing mechanism of conveying public information during the share allocation process. It is not surprising to observe the similar performance between BS and SMP offerings, as a majority of IPOs shares (73.02\%) of BS offerings are actually allocated using SMP offering. Also, the relatively high mean and variance of initial returns for IPOs using bookbuilding are not reduced $(\mu=145.14 \%$ and $\sigma=104.80 \%)$ after the implementation of The Regulation 2004 on January 1st, 2005, suggesting that the institutional change-the introduction of

\footnotetext{
12 The SHSE operates only a Main Board, while the SZSE operates a Main Board as well as the SMEs Board and the Growth Enterprise Board (also known as the ChiNext Board), launched on June 24th, 2004 and on October 30th, 2009, respectively.

${ }^{13}$ The Kruskal-Wallis nonparametric test does not require equal sample sizes and is robust to departures from normality.
} 
bookbuilding into the China stock market - does not contribute to reduce the level of information asymmetry and to counteract the adverse market condition during our sample period.

\section{$<$ Table 3>}

Table 3 shows that the mean and variance of initial returns are persistent for up to 60 trading days (equivalent to three months) after listing. For example, the mean market-adjusted three-month buy-andhold abnormal returns (BHARs) and cumulative abnormal returns (CARs) of all IPOs in our sample are $94.87 \%(\sigma=91.41 \%)$ and $112.70 \%(\sigma=91.02 \%)$, respectively, suggesting that IPO underpricing is not a first day temporary price pressure phenomenon in the China stock market.

\section{$4 \quad$ Empirical results}

\subsection{Preliminaries}

We initially examine whether a specific issuing mechanism is more efficient than others for pricing IPOs. We introduce three dummy variables of $B B, B S$, and $S M P$, which represent BB, BS, and SMP offerings in Eq. (1), respectively; the effect of OFP offering is captured by the intercept term. Also, we include a set of firm-specific variables generally employed as proxies for apparent risk of IPOs to capture the unique features of the China stock market. Specifically, LNSIZE represents the natural logarithm of the raised gross proceeds of the IPO firm in millions of RMB, adjusted using CPI (2005 = 100); TECH is a dummy variable set to one if the IPO firm has some high-tech related contents based on the three-digit ICB codes (see Appendix), and zero otherwise; EXG is a dummy variable set to one if the IPO firm is listed on the SHSE, and zero otherwise; STATE represents the fraction of tradable shares by total shares outstanding of the IPO firm; and $R E G$ is a dummy variable set to one if IPO shares are issued after the implementation of The Regulation 2004 on January 1st, 2005, and zero otherwise. ${ }^{14}$ Thus, we regress the market-adjusted initial returns $(I R)$ or the market-adjusted three-month BHARs (BHAR60) of IPOs on all firm-specific control variables, dummy variables of issuing mechanisms, along with two indicator variables for years (YEAR) and industries (INDUSTRY) based on the two-digit ICB codes, to control for the potential year and industry fixed effects, respectively. The regression model is presented as follows:

$$
\begin{gathered}
I R \text { or } B H A R 60=\beta_{0}+\beta_{1} L N S I Z E+\beta_{2} T E C H+\beta_{3} E X G+\beta_{4} S T A T E+\beta_{5} R E G+\beta_{6} B B+ \\
\beta_{7} B S+\beta_{8} S M P+Y E A R+I N D U S T R Y+\varepsilon .
\end{gathered}
$$

Table 4 shows that the dummy variable of SMP generates small and statistically insignificant coefficients of $0.2626(t$-stat $=1.40)$ and $0.2100(t$-stat $=1.22)$ in Regressions $(1)$ and $(6)$, respectively, very close to those on $B S$, i.e., $0.2824(t$-stat $=1.58)$ and $0.2253(t$-stat $=1.29)$ in Regressions $(1)$ and $(6)$, respectively, which could be explained by the similar characteristics between BS and SMP offerings, given the fact that a majority of IPOs shares (73.02\%, on average) of BS offerings are actually allocated using SMP offering. ${ }^{15}$ However, the dummy variable of $B B$ generates much higher and statistically significant

\footnotetext{
${ }^{14}$ We test the potential influence of multicollinearity in the regression analyses by calculating the variance inflation factors (VIFs). VIF is defined as $1 /\left(1-R^{2}\right)$, where $R^{2}$ is obtained from the regression of one variable on all other regressors specified in the regression model. All of multiple regressions yield a value of VIF of less than 2.5, much smaller than the commonly accepted threshold of 10, indicating no evidence of multicollinearity in the regression analyses.

${ }^{15}$ Given the limited sample of 18 BS offerings and the fact that over 70\% of IPO shares of BS offerings are actually allocated using SMP offering, we replicate all regression analyses either excluding all BS offerings in our sample or combining BS and SMP
} 
coefficients of $0.5870(t$-stat $=2.37)$ and $0.4489(t$-stat $=2.21)$ in Regressions $(1)$ and $(6)$, respectively, at the 5\% level. Thus, our preliminary results support $\boldsymbol{H 1}$ that, compared bookbuilding, SMP offering is a more efficient issuing mechanism in reducing the level of IPO underpricing.

\section{<Table 4>}

\subsection{The impact of market conditions on the level of IPO underpricing}

We then test whether market conditions (market return and volatility) have an impact on the level of IPO underpricing. Given no specific priors on the length of the pre-offering period that might affect the level of underpricing, we investigate several different time periods which encompass the time frame when an IPO is being planned and implemented. Thus, for each IPO on the SHSE or SZSE, the market return variables are constructed for the one-week (MktRet_lw), one-month (MktRet_lm), and three-month (MktRet_3m) periods before the offering date as an estimate of the buy-and-hold return (BHR) on the SHSE or SZSE AShare Index, respectively. Also, a one-month weighted market return variable (MktRet_3w) is constructed as a weighted average BHR of the corresponding market index return in three months prior to offering. The weights are three for the most recent month, two for the next, and one for the third month prior to offering, based on the assumption that investors' perceptions take the last three months into account, but give heavier weight to recent periods (Derrien and Womack 2003). Thus, we regress $I R$ and BHAR60, separately, on a set of firm-specific control variables, dummy variables of issuing mechanisms, and indicator variables, included in Eq. (1), as well as on each market return variable. The regression model is presented as follows:

$$
\begin{aligned}
I R \text { or } B H A R 60 & =\beta_{0}+\beta_{1} L N S I Z E+\beta_{2} T E C H+\beta_{3} E X G+\beta_{4} S T A T E+\beta_{5} R E G+\beta_{6} B B \\
& +\beta_{7} B S+\beta_{8} S M P+\beta_{9}[\text { Market Return Variable }]+Y E A R+I N D U S T R Y \\
& +\varepsilon .
\end{aligned}
$$

The left side of Table 4 shows that all market return variables are statistically and economically positive and significant in Regressions (2-5) with the use of $I R$ as the dependent variable. For example, in Regression (5), the market return variable of MktRet_3w is statistically significant at the $1 \%$ level $(t$-stat $=$ 4.17), while the coefficient of 3.0158 also suggests that an increase on market return of $1 \%$ monthly, on average, gives rise to an additional increase of $3.0158 \%$ on the first day return. In addition, the explanatory power of Regression (5), an adjusted $R^{2}$ of 0.2631 , is driven by the market return variable, as the adjusted $R^{2}$ is substantially reduced to 0.0637 in Regression (1) when the market return variable is not included. The right side of Table 4 shows a similarly positive impact of market return on the short-run underpricing of IPOs in Regressions (7-10), using BHAR60 as the dependent variable. In the rest of the study, we report the results with the use of $M k t R e t \_3 w$ as the major market return variable.

We further test whether market conditions in terms of market volatility $\left(M k t V o l \_l m\right)$, measured as the standard deviation of the daily return of the relevant SHSE or SZSE A-Share Index in one month prior to offering, have an impact on the level of IPO underpricing. In addition to a set of firm-specific control variables, dummy variables of issuing mechanisms, market return variable of MktRet_3w, and indicator

offerings in a single category. Our results are qualitatively the same, which are not reported for the sake of brevity, but available on request. 
variables, included in Eq. (2), we introduce the market volatility variable of MktVol_lm. The regression model is presented as follows:

$$
\begin{aligned}
\text { IR or BHAR60 } & =\beta_{0}+\beta_{1} L N S I Z E+\beta_{2} \text { TECH }+\beta_{3} E X G+\beta_{4} S T A T E+\beta_{5} R E G+\beta_{6} B B \\
& +\beta_{7} B S+\beta_{8} S M P+\beta_{9} \text { MktRet_3w+ } 310 \text { MktVol_1m }+ \text { YEAR + INDUSTRY } \\
& +\varepsilon .
\end{aligned}
$$

We find that the market volatility variable (similar to the market return variable) also plays an important role in explaining the level of IPO underpricing. For example, the left side of Table 5 shows statistically and economically significant coefficients of $M k t V o l \_l m, 3.8488(t$-stat $=2.67)$ and $3.8161(t$ stat $=2.61$, at the $1 \%$ level, in Regressions (11) and (13), respectively, using IR or BHAR60 as the dependent variable.

\section{<Table 5>}

Market practitioners generally suggest that the typical aim of underwriters is not only to underprice, at least modestly, but also to control aftermarket price variations, especially on the downside (Derrien and Womack 2003). Inferring from this, we would suggest that an efficient issuing mechanism is reflected in lower underpricing and/or lower variance proxied by the cross-sectional squared deviations of IPO underpricing. In this study, we also examine the impact of market conditions on the variance of IPO underpricing, which is assumed to be related to the same firm-specific characteristics that are posited to affect the level of underpricing. The dependent variables of squared deviations of IR and BHAR60 used in Regressions (15) and (17) are constructed as the squared residuals from Regressions (11) and (13), respectively. The right side of Table 5 shows that market conditions in terms of both market return and market volatility have a significantly positive impact on the variance of IPO underpricing.

In sum, the results presented in Table 5 confirm that market conditions, in terms of both market return and volatility in the near-term months before the offering dates, have statistically significant impacts on the mean and variance of initial and short-run underpricing of IPOs.

\subsection{The impact of issuing mechanisms on the control of market conditions}

We finally construct two additional sets of market conditional issuing mechanism (interaction) variables: the products of market return variable of MktRet_3w with each issuing mechanism dummy $\left(M k t R e t \_3 w \times B B, M k t R e t \_3 w \times B S, M k t R e t \_3 w \times O F P\right.$, and MktRet_3w $\left.\times S M P\right)$ to reflect recent market performance and the products of market volatility variable of $M k t V o l \_l m$ with each issuing mechanism dummy (MktVol_Im $\times B B, M k t V o l \_I m \times B S, M k t V o l \_I m \times O F P$, and MktVol_lm $\left.\times S M P\right)$ to reflect potential market risk. The regression model is presented as follows:

$$
\begin{aligned}
R \text { or BHAR60 } & =\beta_{0}+\beta_{1} L N S I Z E+\beta_{2} T E C H+\beta_{3} E X G+\beta_{4} S T A T E+\beta_{5} R E G+\beta_{6} B B+\beta_{7} B S \\
& +\beta_{8} S M P+\beta_{9} M k t R e t \_3 w \times B B+\beta_{10} M k t R e t \_3 w \times B S+\beta_{11} M k t R e t \_3 w \\
& \times \text { OFP }+\beta_{12} M k t M k t \_3 w \times S M P+\beta_{13} M k t V o l \_1 m \times B B+\beta_{14} M k t V o l \_1 m \\
& \times B S+\beta_{15} M k t V o l \_1 m \times O F P+\beta_{16} M k t V o l \_1 m \times S M P+Y E A R \\
& +I N D U S T R Y+\varepsilon .
\end{aligned}
$$


The left side of Table 5 shows different impacts of market conditions on IPO underpricing given each issuing mechanism. Specifically, for BB or OFP offerings, the recent market return has a significantly stronger effect on the level of underpricing than for BS and SMP offerings. For example, Regression (12) shows statistically significant interaction variables of MktRet_3w $\times B B($ coefficient $=4.1027 ; t$-stat $=2.92)$, at the $1 \%$ level, and MktRet_3w $\times O F P($ coefficient $=3.7052 ; t$-stat $=2.42$ ), at the $5 \%$ level, much stronger compared with the statistically insignificant coefficients on MktRet_3w $\times B S$ (coefficient $=1.6762 ; t$-stat $=$ $1.57)$ and MktRet_3w $\times S M P($ coefficient $=1.5463 ; t$-stat $=1.52)$. The untabulated $z$-statistics of difference

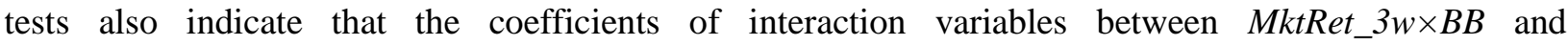
$M k t R e t \_3 w \times S M P(p$-value $=0.0007)$ as well as between $M k t R e t \_3 w \times O F P$ and $M k t R e t \_3 w \times S M P(p$-value $=0.0012$ ) are statistically different at the $1 \%$ level, ${ }^{16}$ suggesting that SMP offering is more efficient in controlling for the effect of market return on IPO underpricing.

We also report the impact of recent market volatility on IPO underpricing across various issuing mechanisms. Table 5 shows that $M k t V o l \_1 m \times B B$ exhibits a statistically significant effect at the $1 \%$ level (coefficient $=3.8999 ; t$-stat $=2.98)$ in Regressions $(12)$, which is much stronger than MktVol_Im $\times O F P$ $($ coefficient $=2.2058 ; t$-stat $=2.04)$ and $M k t V o l \_I m \times S M P($ coefficient $=1.8954 ; t$-stat $=1.28)$. The untabulated $z$-statistics of difference tests also confirm that the coefficients between $M k t V o l \_1 m \times B B$ and $M k t V o l \_1 m \times O F P(p$-value $=0.0028)$ as well as between $M k t V o l \_1 m \times B B$ and MktVol_lm $\times S M P(p$-value $=0.0009)$ are statistically different at the $1 \%$ level. Overall, bookbuilding seems particularly prone to market conditions - an increase of 1\% in market return (volatility) is associated with $4.1027 \%$ (3.8999\%) increase in the level of IPO underpricing. Similar results are found in Regression (14) with the use of BHAR60 as the dependent variable, confirming that when compared with bookbuilding (which is more sensitive to the market return and volatility), SMP offering is more efficient in controlling for the effect of market conditions on both initial and short-run underpricing.

Finally, Regression (16) explaining squared deviations of $I R$ shows that both market return and volatility variables are positively correlated with the variability of IPO underpricing, the result of which is mostly driven by the higher cross-sectional variability in bookbuilding. Specifically, in Regression (16), the untabulated $z$-statistics of difference tests show that the coefficient on MktRet_3w $\times B B, 1.7161(t$-stat $=$ $2.21)$, is significantly different from that of MktRet_3w $\times S M P, 0.2345(t$-stat $=0.27)$, at the $1 \%$ level $(p$ value $=0.0008)$, and from that of MktRet_3w $\times O F P, 0.6629(t$-stat $=2.09)$, at the 5\% level ( $p$-value $=$ 0.0228). Also, the interaction variable of $M k t V o l \_I m \times B B$ generates a coefficient of $1.5563(t$-stat $=2.80)$, which is significantly stronger than that of MktVol_lm $\times S M P, 0.1574(t$-stat $=0.69)$, at the $1 \%$ level $(p$ value $=0.0017)$, and significantly stronger than that of $M k t V o l \_l m \times O F P, 0.9038(t$-stat $=1.85)$, at the 5\% level ( $p$-value $=0.0291)$. Similar results are presented in Regression (18) with the use of the squared deviation of BHAR60 as the dependent variable. Thus, we confirm that the variability of initial and shortrun underpricing is more sensitive to market volatility for bookbuilding than for SMP and OFP offerings.

\footnotetext{
${ }^{16}$ Following Clogg et al. (1995), we employ $z$-statistics to test the statistical difference between the two interaction coefficients: $z=\left(\beta_{a}-\beta_{b}\right) /\left(S E \times \beta_{a}^{2}+S E \times \beta_{b}^{2}\right)^{1 / 2}$.
} 
In sum, the two sets of market condition results support $\boldsymbol{H 2}$ that, from a conditional point of view, SMP offering is more efficient in counteracting adverse market conditions as it seems to be largely immune from the impact of market return and volatility.

\section{$5 \quad$ Robustness tests}

\subsection{Controlling for the problem of endogeneity}

Much theoretical and empirical literature suggests that the choice of IPO issuing mechanism might be endogenously determined (see Ljungqvist and Wihelm 2002; Derrien and Womack 2003). If this is the case, the problem of endogeneity could possibly bias our previous regression coefficients and conclusions. To address the potential self-selection bias and to confirm the validity of our previous conclusions, we employ the Heckman (1979) two-stage procedure in this subsection.

In the first-stage regression, we use a probit model to estimate the probability that an issuer tends to choose SMP offering. The dependent variable is a binary dummy variable set to one if the issuer chooses SMP offering, and zero otherwise. Inspired by Ljungqvist and Wihelm (2002) and Derrien and Womack (2003), we choose four additional variables, which are exogenous with respect to IPO underpricing. For example, $L N(A G E+1)$ represents the natural logarithm of one plus the number of years since the founding year of the IPO firm as of the offering date; $L N L A G$ represents the natural logarithm of the number of days between the offering and listing dates; $B M$ represents the book to market value of the IPO firm as of the offering date; and NUMBER represents the number of IPOs issued during the six weeks before to two weeks after the offering date. In order to confirm that these variables are unlinked with IPO underpricing, we regress the dependent variables of $I R$ and BHAR60, separately, on each chosen exogenous variable and eliminate both $L N(A G E+1)$ and $B M$ that exhibit coefficients with $p$-values of less than $10 \%$. The first-stage probit regression (selection equation) is presented as follows:

$$
\begin{aligned}
& \text { Probability of choosing SMP offering } \\
& \qquad \begin{aligned}
& \alpha_{0}+\alpha_{1} L N L A G+\alpha_{2} N U M B E R+\alpha_{3} L N S I Z E+\alpha_{4} T E C H+\alpha_{5} E X G \\
& +\alpha_{6} S T A T E+\alpha_{7} \text { MktRet_3w }+\alpha_{8} M k t V o l \_1 m+Y E A R+I N D U S T R Y+\xi .
\end{aligned}
\end{aligned}
$$

The second-stage OLS regression includes the inverse Mills ratio $(\lambda)$ derived from the first-stage regression as an additional regressor to correct for the self-selection bias. Specifically, $\lambda_{i}=$ $\phi\left(\gamma Z_{i}\right) /\left[1-\Phi\left(\gamma Z_{i}\right)\right]$, where $\phi$ represents the standard normal density function; $\Phi$ represents the standard normal cumulative distribution function; $\gamma$ represents the first-stage probit estimation of the selection equation; and $Z$ represents the corresponding explanatory variables in the probit regression. The secondstage OLS regression is presented as follows:

$$
\begin{aligned}
\text { IR or BHAR60 } & =\beta_{0}+\beta_{1} L N S I Z E+\beta_{2} T E C H+\beta_{3} E X G+\beta_{4} S T A T E+\beta_{5} S T A T E+\beta_{6} S M \\
& +\beta_{7} M k t R e t \_3 w \times B B+\beta_{8} M k t V o l \_1 m \times S M P+\beta_{9} M k t V o l \_1 m \times B B \\
& +\beta_{10} M k t V o \_1 m \times S M P+\beta_{11} \lambda+Y E A R+I N D U S T R Y+\varepsilon .
\end{aligned}
$$

Table 6 reports the Heckman (1979) two-stage regression results, based on a sample of 479 IPOs using either BB or SMP offering, again confirming that previous conclusions still hold up fairly well after controlling for the problem of endogeneity. Specifically, the first-stage regression results in Regression (19) 
suggest the presence of a self-selection bias. For example, the coefficient on the market return variable of MktRet_3w is significantly negative at the $1 \%$ level (coefficient $=-2.4509 ; t$-stat $=-2.68$ ), while the coefficient on the market volatility variable of $M k t V o l \_l m$ is significantly positive at the $1 \%$ level (coefficient $=1.7798 ; t$-stat $=2.63)$, the results of which imply that issuers are more likely to choose SMP offering in a declining market with heavy uncertainty. The McFadden $R^{2}$ of 0.5421 indicates a strong explanatory power of the selection equation.

\section{$<$ Table 6>}

In addition, Table 6 shows that the inverse Mills ratio in the second-stage OLS regression is significantly positive in Regressions (20-23) at the 5\% level. The statistical significance of $\lambda$ implies the importance of taking the problem of endogeneity into account. The second-stage regression results show that the coefficients and statistical significances of other independent variables remain qualitatively similar to those presented in Table 5, again confirming that SMP offering is more efficient in controlling for adverse market conditions in the form of lower market return and/or higher market volatility.

\subsection{Out-of-sample test}

To further test the robustness of our results, we extend our analysis to account for the potential influence of the exchange of listing. Specifically, since the launch of the SMEs Board in June 2004, the SZSE has been specially designed for young, small and medium size firms in the high-tech industry sector, while the SHSE features more established firms. As such, both stock exchanges are likely to have different risk profiles that will influence the level of IPO underpricing. Therefore, we replicate all tests in Table 5, exclusively using an out-of-sample of 343 IPOs on the SHSE over the period April 2001 to October 2012: 146 for BB, 26 for OFP, and 171 for SMP. The regression results shown in Table 7 are qualitatively the same as those presented in Table 5.

\section{$<$ Table 7>}

\subsection{More robustness tests}

We conduct several additional robustness tests. For example, we winsorize the extreme values of the dependent variable of $I R$ and BHAR60 at $1 \%$ and $99 \%$ prior to regression estimation, to avoid any potential misleading conclusions resulted from outliers. The results based on a trimmed sample are qualitatively the same, suggesting that outliers do not appear to be driving the results. Also, we use the pre-listing market condition variables in all regression equations, and again our results are qualitatively similar to those based on the pre-offering market condition variables.

Furthermore, Appendix shows that a total of 15 utilities (14 listed on the SHSE and one on the SZSE) are included in our sample. Of the 15 utilities, five use bookbuilding, eight are SMP offerings, and two are BS offerings. We replicate all regression analyses with the use of a subsample of 508 IPOs excluding the 15 utilities. The regression results confirm that our previous conclusions-SMP offering leads to lower underpricing and lower cross-sectional variation of short-run returns of IPOs; SMP offering is better able to counteract adverse market conditions in the form of low market return and/or high market volatility- 
remain qualitatively unchanged. These results are not reported for the sake of brevity, but available on request.

\section{Conclusions}

The existence of several basic and substantially different issuing mechanisms in the China stock market offers an ideal arena to address the challenging question of which issuing mechanism is more efficient for pricing IPOs. This study aims to test two possible criteria for assessing the efficiency of any given IPO issuing mechanism, that is, whether an efficient issuing mechanism is able to lead to less underpricing and lower cross-sectional variation of initial returns, and able to counteract adverse market conditions in the form of low market returns and/or high market volatility (Derrien and Womack 2003). Our empirical results show that, compared with bookbuilding, SMP offering is associated with greater efficiency for pricing IPOs in the face of adverse market conditions. Our results are robust to various alternative tests after controlling for the problem of endogeneity and for the influence of exchange of listing.

Our results highlight the difficulty of underwriters in accurately pricing IPOs and cast doubts on bookbuilding as an efficient issuing mechanism of conveying public information during the share allocation process. Specifically, if the market is volatile and signals are noisy, then the impact of information flows on different investor groups becomes blurred. We could expect the IPO price distribution to be wider and underpricing to grow faster in a volatile market than that observed under a benign market condition (Beatty and Ritter, 1986). In this type of situation, the price-based market mechanism cannot ex ante fully resolve uncertainty relating even to public information; investors naturally then look to non-price information signals, and one approach for less-informed investors is to rely heavily on the purchasing actions of informed investors.

It is in this context that SMP offering has an advantage over other issuing mechanisms, as it makes the use of secondary market existing investors as signal conduits. These experienced investors who are holding shares in the secondary market have phenomenal knowledge of share ownership of listed firms in different market conditions and are better able to deal with noisy signals. Their behavior could be intentionally followed by less-informed investors in making decisions concerning potential IPO investment. Therefore, the quality of signals is expected to be better in SMP offering. As a transitional institutional setting, SMP offering was built on the existence of the split-share structure in the China stock market, in attempts to reduce the IPO subscription costs for investors in the secondary market. However, with the formal launch of the split-share structure reform in 2005, non-tradable shares were gradually converted into tradable shares and the foundation of SMP offering thus no longer existed. In recent years, the CSRC have formulated a series of regulations in attempts to establish a more market-oriented issuing mechanism in the China stock market. Whether these reforms really enhance the efficiency of the bookbuilding process and have significant influence on price discovery is left for future research. 


\section{Appendix: Distribution of all IPOs by the industry category}

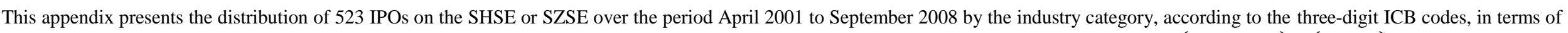

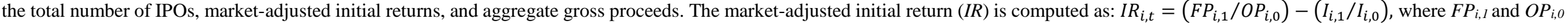

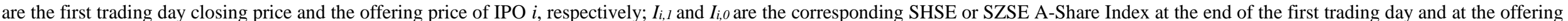
day of IPO $i$, respectively. The gross proceeds are presented in millions of RMB, adjusted using CPI $(2005=100)$. Like Loughran and Ritter (2004) and Su and Bangassa (2011a, b), we define IPO

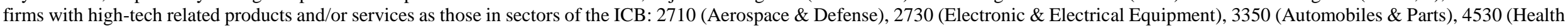
Care Equipment \& Services), 4570 (Pharmaceuticals \& Biotechnology), 6570 (Mobile Telecommunications), 9530 (Software \& Computer Services), and 9570 (Technology Hardware \& Equipment). The final three rows summarize the distribution of 161 high-tech related IPOs, of 362 non-high-tech related IPOs, and of the full sample.

\begin{tabular}{|c|c|c|c|c|c|c|c|c|c|c|c|}
\hline \multirow[b]{2}{*}{ Industry } & \multirow[b]{2}{*}{ Super-sector } & \multirow[b]{2}{*}{ Sector } & \multicolumn{3}{|c|}{ SHSE } & \multicolumn{3}{|c|}{ SZSE } & \multicolumn{3}{|c|}{ Whole market } \\
\hline & & & No. & $I R(\%)$ & $\begin{array}{r}\text { Gross } \\
\text { proceeds }\end{array}$ & No. & $I R(\%)$ & $\begin{array}{r}\text { Gross } \\
\text { proceeds }\end{array}$ & No. & $I R(\%)$ & $\begin{array}{r}\text { Gross } \\
\text { proceeds }\end{array}$ \\
\hline \multirow[t]{3}{*}{0001 Oil \& Gas } & 0500 Oil \& Gas & 0530 Oil \& Gas Producers & 2 & 152.67 & $63,164.61$ & 1 & 209.93 & 283.19 & 3 & 171.76 & $63,447.80$ \\
\hline & & 0570 Oil Equipment, Services, \& Distribution & 2 & 122.75 & $7,162.88$ & 2 & 150.40 & $1,115.58$ & 4 & 136.58 & $8,278.46$ \\
\hline & & 0580 Alternative Energy & - & - & - & 2 & 164.86 & $2,148.14$ & 2 & 164.86 & $2,148.14$ \\
\hline \multirow{4}{*}{1000 Basic Materials } & 1300 Chemicals & 1350 Chemicals & 15 & 105.01 & $5,163.37$ & 35 & 127.48 & $10,127.41$ & 50 & 120.74 & $15,290.78$ \\
\hline & 1700 Basic Resources & 1730 Forestry \& Paper & 6 & 153.94 & $2,254.99$ & 5 & 93.89 & $2,345.43$ & 11 & 126.64 & $4,600.42$ \\
\hline & & 1750 Industrial Metals \& Mining & 21 & 87.32 & $25,892.29$ & 10 & 184.79 & $3,560.72$ & 31 & 118.76 & $29,453.00$ \\
\hline & & 1770 Mining & 16 & 82.82 & $108,821.96$ & 3 & 230.57 & $2,425.81$ & 19 & 106.15 & $111,247.77$ \\
\hline \multirow[t]{7}{*}{2000 Industrials } & 2300 Construction \& Materials & 2350 Construction \& Materials & 20 & 71.97 & $49,207.04$ & 22 & 114.00 & $7,661.04$ & 42 & 93.99 & $56,868.08$ \\
\hline & 2700 Industrial Goods \& Services & 2710 Aerospace \& Defense & 8 & 107.79 & $3,672.42$ & 2 & 107.09 & 747.27 & 10 & 107.65 & $4,419.69$ \\
\hline & & 2720 General Industrials & 1 & 54.41 & 253.86 & 5 & 59.47 & $2,140.62$ & 6 & 58.63 & $2,394.48$ \\
\hline & & 2730 Electronic \& Electrical Equipment & 15 & 162.34 & $4,222.57$ & 41 & 165.31 & $11,556.88$ & 56 & 164.51 & $15,779.45$ \\
\hline & & 2750 Industrial Engineering & 27 & 119.89 & $15,434.86$ & 25 & 163.01 & $6,937.18$ & 52 & 140.62 & $22,372.04$ \\
\hline & & 2770 Industrial Transportation & 17 & 74.31 & $60,722.77$ & 3 & 155.40 & $1,253.91$ & 20 & 86.47 & $61,976.68$ \\
\hline & & 2790 Support Services & 1 & 267.89 & 153.65 & 4 & 94.09 & 887.25 & 5 & 128.85 & $1,040.90$ \\
\hline \multirow[t]{6}{*}{3000 Consumer Goods } & 3300 Automobiles \& Parts & 3350 Automobiles \& Parts & 4 & 43.95 & $2,369.82$ & 10 & 101.79 & $2,145.06$ & 14 & 85.26 & $4,514.88$ \\
\hline & 3500 Food \& Beverage & 3530 Beverages & 4 & 86.94 & $3,383.16$ & - & - & - & 4 & 86.94 & $3,383.16$ \\
\hline & & 3570 Food Producers & 16 & 111.54 & $8,183.18$ & 13 & 147.14 & $4,170.53$ & 29 & 127.49 & $12,353.71$ \\
\hline & 3700 Personal \& Household Goods & 3720 Household Goods \& Home Construction & 3 & 64.60 & 909.22 & 12 & 96.75 & $4,320.13$ & 15 & 90.32 & $5,229.35$ \\
\hline & & 3740 Leisure Goods & - & - & - & 3 & 97.26 & 888.45 & 3 & 97.26 & 888.45 \\
\hline & & 3760 Personal Goods & 11 & 41.76 & $5,106.68$ & 19 & 111.73 & $5,272.11$ & 30 & 86.07 & $10,378.79$ \\
\hline \multirow[t]{2}{*}{4000 Health Care } & 4500 Health Care & 4530 Health Care Equipment \& Services & 2 & 106.61 & 623.75 & 1 & 65.30 & 219.05 & 3 & 92.84 & 842.81 \\
\hline & & 4570 Pharmaceuticals \& Biotechnology & 20 & 115.86 & $8,941.52$ & 13 & 109.76 & $2,841.48$ & 33 & 113.46 & $11,783.01$ \\
\hline \multirow[t]{4}{*}{5000 Consumer Services } & 5300 Retail & 5330 Food \& Drug Retailers & 1 & 115.34 & 419.41 & 2 & 124.36 & $1,097.05$ & 3 & 121.35 & $1,516.46$ \\
\hline & & 5370 General Retailers & 2 & 131.68 & 648.41 & 2 & 169.06 & 855.24 & 4 & 150.37 & $1,503.65$ \\
\hline & 5500 Media & 5550 Media & 1 & 327.65 & 611.16 & 2 & 190.50 & 908.90 & 3 & 236.21 & $1,520.06$ \\
\hline & 5700 Travel \& Leisure & 5750 Travel \& Leisure & 7 & 109.40 & $19,560.69$ & 4 & 209.07 & 916.89 & 11 & 145.64 & $20,477.58$ \\
\hline 6000 Telecommunications & 6500 Telecommunications & 6570 Mobile Telecommunications & 1 & 29.12 & $12,304.73$ & 2 & 180.95 & 486.57 & 3 & 130.34 & $12,791.30$ \\
\hline \multirow[t]{2}{*}{7000 Utilities } & 7500 Utilities & 7530 Electricity & 12 & 94.21 & $22,681.80$ & 1 & 50.58 & 298.50 & 13 & 90.85 & $22,980.30$ \\
\hline & & 7570 Gas, Water, \& Multiutilities & 2 & 102.99 & 493.84 & - & - & - & 2 & 102.99 & 493.84 \\
\hline \multirow[t]{2}{*}{9000 Technology } & 9500 Technology & 9530 Software \& Computer Services & 10 & 101.59 & $3,504.78$ & 11 & 167.35 & $2,446.54$ & 21 & 136.04 & $5,951.32$ \\
\hline & & 9570 Technology Hardware \& Equipment & 9 & 76.91 & $4,692.96$ & 12 & 132.87 & $4,523.24$ & 21 & 108.89 & $9,216.20$ \\
\hline High-tech related firms & & & 69 & 112.19 & $40,332.55$ & 92 & 144.56 & $24,966.11$ & 161 & 130.68 & $65,298.66$ \\
\hline Non-high-tech related firms & & & 187 & 96.60 & $400,229.84$ & 175 & 133.59 & $59,614.07$ & 362 & 114.48 & $459,843.91$ \\
\hline Total & & & 256 & 100.80 & $440,562.39$ & 267 & 137.37 & $84,580.18$ & 523 & 119.47 & $525,142.57$ \\
\hline
\end{tabular}




\section{References}

Balvers RJ, Affleck-Graves J, Miller RE, Scanlon K (1993) The underpricing of initial public offerings: A theoretical and empirical reconsideration of the adverse selection hypothesis. Rev Quant Financ Acc 3:221-239

Beatty RP, Ritter JR (1986) Investment banking, reputation, and the underpricing of initial public offerings. J Financ Econ 15:213-232

Benveniste LM, Spindt PA (1989) How investment banks determine the offer price and allocation of new issues. J Financ Econ 24:343-362

Benveniste LM, Wilhelm WJ (1990) A comparative analysis of IPO proceeds under alternative regulatory environments. J Financ Econ 28:173-207

Biais B, Faugeron-Crouzet AM (2002) IPO auctions: English, Dutch, ... French, and Internet. J Financ Intermed 11:9-36

Binay MW, Gatchev VA, Pirinsk CA (2007) The role of underwriter-investor relationship in the IPO process. J Financ Quant Anal 42:785-810

Bradley DJ, Jordan BD (2002) Partial adjustment to public information and IPO underpricing. J Financ Quant Anal 37:595-616

Busaba WY, Chang C (2010) Bookbuilding vs. fixed price revisited: The effect of aftermarket trading. J Corp Financ 16:370-381

Chan K, Wang JB, Wei KC (2004) Underpricing and long-term performance of IPOs in China. J Corp Financ 10:409-430

Clogg CC, Petkova E, Haritou A (1995) Statistical methods for comparing regression coefficients between models. Am J Sociol 100:1261-1293

Degeorge F, Derrien F, Womack KL (2010) Auctioned IPOs: The US evidence. J Financ Econ 98:177-194

Deng Q, Zhou Z-G (2016) The pricing of first day opening price returns for ChiNext IPOs. Rev Quant Financ Acc 47:249-271

Derrien F, Womack KL (2003) Auctions vs. bookbuilding and control of under-pricing in hot IPO markets. Rev Financ Stud 16:31-61

Guo H, Brooks R (2008) Underpricing of Chinese A-share IPOs and short-run underperformance under the approval system from 2001 to 2005. Int Rev Financ Anal 17:984-997

Heckman JJ (1979) Sample selection bias as a specification error. Econometrica 47:153-161

Houston J, James C, Karceski J (2006) What a difference a month makes: Stock analyst valuations following initial public offerings. J Financ Quant Anal 41:111-137

Jagannathan R, Jirnyi A, Sherman AG (2015) Share auctions of initial public offerings: Global evidence. J Financ Intermed 24:283-311

Kennedy DB, Sivakumar R, Vetzal KR (2006) The implications of IPO underpricing for the firm and insiders: Tests of asymmetric information theories. J Empir Financ 13:49-78

Krigman L, Shaw W, Womack KL (2001) Why do firms switch underwriters? J Financ Econ 60:245-284

Ljungqvist AP (2007) IPO underpricing. In: Eckbo BE (Ed.), Handbook of Corporate Finance: Empirical Corporate Finance, Vol. 1. New York, NY.

Ljungqvist AP, Jenkinson T, Wilhelm WJ (2003) Global integration in primary equity markets: The role of U.S. banks and U.S. investors. Rev Financ Stud 16:63-99

Ljungqvist AP, Nanda VK, Singh R (2006) Hot markets, investor sentiment and IPO pricing. J Bus 79:1667-1702

Ljungqvist AP, Wihelm WJ (2002) IPO allocations: Discriminatory or discretionary? J Financ Econ 65:167-201

Loughran T, Ritter JR (1995) The new issues puzzle. J Financ 50:23-51

Loughran T, Ritter JR (2002) Why don't issuers get upset about leaving money on the table in IPOs? Rev Financ Stud 15:413-443

Loughran T, Ritter JR (2004) Why has IPO underpricing changed over time? Financ Manage 33:5-37 
Loughran T, Ritter JR, Rydqvist K (1994) Initial public offerings: International insights. Pac-Basin Financ J 2:165-199

Lowry M, Officer MS, Schwert GW (2010) The variability of IPO initial returns. J Financ 65:425-465

Lowry M, Schwert GW (2004) Is the IPO pricing process efficient? J Financ Econ 71:3-26

Lyon JD, Barber B, Tsai CL (1999) Improved methods for tests of long run abnormal stock returns. J Financ 54:165-201

Ma S, Faff R (2007) Market conditions and the optimal IPO allocation mechanism in China. Pac-Basin Financ J 15:121-139

Mantell EH (2016) A theory of underwriters' risk management in a firm-commitment initial public offering. Rev Quant Financ Acc 46:179-193

Mok HMK, Hui YN (1998) Underpricing and aftermarket performance of IPOs in Shanghai, China. PacBasin Financ J 6:453-474

Neupane S, Poshakwale SS (2012) Transparency in IPO mechanism: Retail investors' participation, IPO pricing and returns. J Bank Financ 36:2064-2076

Ritter JR (1991) The long-run performance of initial public offerings. J Financ 46:3-27

Ritter JR (2002) Investment banking and securities issuance. In: Constantinides G, Harris M, Stulz R (Eds.), Handbook of the Economics of Finance. New York, NY.

Ritter JR (2003) Differences between European and American IPO markets. Eur Financ Manag 9:421-434

Ritter JR, Welch I (2002) A review of IPO activity, pricing, and allocations. J Financ 57:1795-1828

Rock K (1986) Why new issues are underpriced. J Financ Econ 15:187-212

Sherman AE (2000) IPOs and long term relationships: An advantage of book building. Rev Financ Stud 13:697-714

Sherman AE (2005) Global trends in IPO methods: Book building versus auctions with endogenous entry. J Financ Econ 78:615-649

Sherman AE, Titman S (2002) Building the IPO order book: Underpricing and participation limits with costly information. J Financ Econ 65:3-29

Su C (2015) Does institutional reform improve the impact of investment bank reputation on the long-term stock performance of initial public offerings? Brit Account Rev 47:445-470

Su C, Bangassa K (2011) The impact of underwriter reputation on initial returns and long-run performance of Chinese IPOs. J Int Financ Mark I 21:760-791

Su C, Bangassa K (2011) Underpricing and long run performance of Chinese IPOs: The role of underwriter reputation. Financ Mark Portf Manag 25:53-74

Yong O (2007) A review of IPO research in Asia: What's next? Pac-Basin Financ J 15:253-275

Zhou Z, Zhou J (2010) Chinese IPO activity, pricing, and market cycles. Rev Quant Financ Acc 34:483503 
Table 1 Distribution of IPOs by the year of listing

\begin{tabular}{|c|c|c|c|c|c|c|c|c|c|}
\hline & \multicolumn{3}{|c|}{ SHSE } & \multicolumn{3}{|c|}{ SZSE } & \multicolumn{3}{|c|}{ Whole Market } \\
\hline & No. & $\operatorname{IR}(\%)$ & Gross proceeds & No. & $\operatorname{IR}(\%)$ & Gross proceeds & No. & $\operatorname{IR}(\%)$ & Gross proceeds \\
\hline 2001 & 36 & 156.54 & $26,372.18$ & - & - & - & 36 & 156.54 & $26,372.18$ \\
\hline 2002 & 66 & 127.79 & $41,305.98$ & - & - & - & 66 & 127.79 & $41,305.98$ \\
\hline 2003 & 65 & 72.40 & $42,016.54$ & - & - & - & 65 & 72.40 & $42,016.54$ \\
\hline 2004 & 58 & 72.72 & $23,727.29$ & 37 & 71.17 & $9,083.26$ & 95 & 72.11 & $32,810.55$ \\
\hline 2005 & 3 & 76.34 & $2,854.54$ & 12 & 42.11 & $2,908.53$ & 15 & 48.95 & $5,763.07$ \\
\hline 2006 & 9 & 36.76 & $45,029.21$ & 56 & 92.59 & $17,576.35$ & 65 & 84.86 & $62,605.56$ \\
\hline 2007 & 14 & 141.43 & $194,064.67$ & 93 & 211.69 & $29,728.67$ & 107 & 202.50 & $223,793.34$ \\
\hline 2008 & 5 & 54.48 & $65,191.98$ & 69 & 125.60 & $25,283.37$ & 74 & 120.79 & $90,475.35$ \\
\hline $2001-2005$ & 228 & 101.85 & $136,276.53$ & 49 & 64.05 & $11,991.79$ & 277 & 95.16 & $148,268.32$ \\
\hline $2006-2008$ & 28 & 92.26 & $304,285.86$ & 218 & 153.85 & $72,588.39$ & 246 & 146.84 & $376,874.25$ \\
\hline Total & 256 & 100.80 & $440,562.39$ & 267 & 137.37 & $84,580.18$ & 523 & 119.47 & $525,142.57$ \\
\hline
\end{tabular}

This table presents the distribution of 523 IPOs on the SHSE or SZSE over the period April 2001 to September 2008 by the year of listing, in terms of the number of IPOs, market-adjusted initial returns, and aggregate gross proceeds. The market-adjusted initial return $(I R)$ is computed as: $I R_{i, t}=\left(F P_{i, 1} / O P_{i, 0}\right)-\left(I_{i, 1} / I_{i, 0}\right)$, where $F P_{i, l}$ and $O P_{i, 0}$ are the first trading day closing price and the offering price of IPO $i$, respectively; $I_{i, l}$ and $I_{i, 0}$ are the corresponding SHSE or SZSE A-Share Index at the end of the first trading day and at the offering day of IPO $i$, respectively. The gross proceeds are presented in millions of RMB, adjusted using CPI (2005 $=100)$. 
Table 2 Descriptive statistics of IPOs across various issuing mechanisms

\begin{tabular}{|c|c|c|c|c|c|}
\hline & BB & BS & OFP & SMP & ALL \\
\hline 2001 & 10 & 0 & 26 & 0 & 36 \\
\hline 2002 & 18 & 0 & 0 & 48 & 66 \\
\hline 2003 & 0 & 0 & 0 & 65 & 65 \\
\hline 2004 & 0 & 0 & 0 & 95 & 95 \\
\hline 2005 & 0 & 15 & 0 & 0 & 15 \\
\hline 2006 & 65 & 0 & 0 & 0 & 65 \\
\hline 2007 & 104 & 3 & 0 & 0 & 107 \\
\hline 2008 & 74 & 0 & 0 & 0 & 74 \\
\hline SHSE & 56 & 3 & 26 & 171 & 256 \\
\hline SZSE & 215 & 15 & 0 & 37 & 267 \\
\hline High-tech related issuers & 82 & 3 & 9 & 67 & 161 \\
\hline Non-high-tech related issuers & 189 & 15 & 17 & 141 & 362 \\
\hline Pre-The Regulation 2004 & 28 & - & 26 & 208 & 262 \\
\hline Post-The Regulation 2004 & 243 & 18 & - & - & 261 \\
\hline Total & 271 & 18 & 26 & 208 & 523 \\
\hline$L A G$ & 13.79 & 15.39 & 23.23 & 15.97 & 15.18 \\
\hline STATE $(\%)$ & 21.17 & 24.12 & 31.76 & 32.81 & 26.43 \\
\hline SIZE & $1,450.23$ & 365.24 & 780.88 & 506.03 & $1,004.10$ \\
\hline Mean of $I R(\%)$ & 145.08 & 88.11 & 149.61 & 85.04 & 119.47 \\
\hline Pre-The Regulation 2004 & 144.55 & - & 149.61 & 85.04 & 97.78 \\
\hline Post-The Regulation 2004 & 145.14 & 88.11 & - & - & 141.21 \\
\hline Standard deviation $(S D)$ of $I R(\%)$ & 102.30 & 69.98 & 100.00 & 62.98 & 93.33 \\
\hline Pre-The Regulation 2004 & 85.32 & - & 100.00 & 62.98 & 74.49 \\
\hline Post-The Regulation 2004 & 104.80 & 69.98 & - & - & 104.61 \\
\hline Pre-offering market return (\%) & 2.46 & -2.09 & -0.85 & -1.23 & 0.67 \\
\hline Pre-offering market volatility (\%) & 2.07 & 1.52 & 1.00 & 1.14 & 1.63 \\
\hline Pre-listing market return $(\%)$ & 2.48 & -3.35 & -1.71 & -1.52 & 0.48 \\
\hline Pre-listing market volatility (\%) & 2.08 & 1.51 & 1.19 & 1.12 & 1.63 \\
\hline
\end{tabular}

This table presents descriptive statistics of 523 IPOs on the SHSE or SZSE over the period April 2001 to September 2008 across various issuing mechanisms: bookbuilding (BB); secondary market proportional offering (SMP); bookbuilding plus secondary market proportional offering (BS); and online fixed price offering (OFP).

High-tech related issuers are confirmed when the IPO firm has some high-tech related contents, according to the ICB (see the distribution of all IPOs in our sample by the industry category in Appendix). All issuers are also identified by whether they are issued before or after implementing The Regulation 2004 on January 1st, 2005. LAG represents the gap (calendar days) between the offering and listing dates; STATE represents the fraction of tradable shares by total shares outstanding of the IPO firm; SIZE represents the raised aggregate gross proceeds of the IPO firm in millions of RMB, adjusted using CPI $(2005=100)$; the marketadjusted initial return $(I R)$ is computed as: $I R_{i, t}=\left(F P_{i, 1} / O P_{i, 0}\right)-\left(I_{i, 1} / I_{i, 0}\right)$, where $F P_{i, 1}$ and $O P_{i, 0}$ are the first trading day closing price and the offering price of IPO $i$, respectively; $I_{i, l}$ and $I_{i, 0}$ are the corresponding SHSE or SZSE A-Share Index at the end of the first trading day and at the offering day of IPO $i$, respectively; Pre-offering (Pre-listing) market return represents the weighted average buy-and-hold return (BHR) of the corresponding returns on the SHSE or SZSE A-Share Index in three months prior to offering (prior to listing), where the weights are 3 for the most recent month, 2 for the next, and 1 for the third month prior to offering (Derrien and Womack 2003); Pre-offering (Pre-listing) market volatility represents the standard deviations of the daily returns of the relevant SHSE or SZSE A-share Index in one month prior to offering (prior to listing). 
Table 3 Market-adjusted short-run returns of IPOs across various issuing mechanisms

\begin{tabular}{|c|c|c|c|c|c|c|c|c|c|c|}
\hline & \multicolumn{2}{|c|}{ BB } & \multicolumn{2}{|l|}{ BS } & \multicolumn{2}{|c|}{ OFP } & \multicolumn{2}{|c|}{ SMP } & \multicolumn{2}{|c|}{ ALL } \\
\hline & Mean $(\%)$ & SD $(\%)$ & Mean (\%) & SD $(\%)$ & Mean (\%) & $\mathrm{SD}(\%)$ & Mean (\%) & SD $(\%)$ & Mean (\%) & SD $(\%)$ \\
\hline \multicolumn{11}{|c|}{ Panel A: Buy-and-hold abnormal returns (BHARs) } \\
\hline 5 & 138.22 & 97.34 & 42.00 & 38.19 & 142.41 & 96.34 & 78.70 & 61.26 & 112.00 & 89.15 \\
\hline 10 & 136.53 & 98.18 & 44.49 & 40.82 & 136.86 & 94.39 & 74.91 & 61.85 & 109.40 & 89.88 \\
\hline 20 & 134.69 & 101.16 & 41.97 & 43.06 & 127.07 & 90.46 & 69.61 & 60.76 & 105.77 & 91.58 \\
\hline 30 & 132.28 & 97.81 & 38.20 & 46.45 & 115.07 & 87.96 & 65.63 & 59.75 & 102.22 & 89.50 \\
\hline 40 & 134.96 & 101.41 & 40.78 & 44.27 & 103.24 & 81.43 & 59.90 & 60.26 & 100.83 & 92.73 \\
\hline 60 & 130.31 & 96.84 & 39.07 & 49.90 & 90.63 & 76.47 & 52.74 & 63.95 & 94.87 & 91.41 \\
\hline \multicolumn{11}{|c|}{ Panel B: Cumulative abnormal returns (CARs) } \\
\hline 5 & 146.60 & 103.04 & 48.95 & 31.88 & 149.61 & 100.00 & 85.04 & 62.98 & 119.47 & 93.33 \\
\hline 10 & 143.33 & 101.70 & 43.77 & 34.64 & 147.82 & 100.24 & 82.57 & 63.12 & 116.53 & 92.58 \\
\hline 20 & 141.52 & 101.00 & 45.62 & 36.42 & 146.95 & 99.48 & 81.52 & 63.51 & 115.18 & 92.09 \\
\hline 30 & 139.44 & 101.25 & 48.20 & 35.22 & 146.57 & 98.48 & 80.41 & 63.54 & 113.70 & 91.97 \\
\hline 40 & 138.56 & 99.48 & 50.55 & 34.41 & 147.06 & 97.86 & 79.71 & 63.33 & 113.05 & 90.79 \\
\hline 60 & 138.76 & 99.71 & 52.00 & 32.82 & 146.87 & 97.36 & 78.47 & 63.20 & 112.70 & 91.02 \\
\hline
\end{tabular}

This table presents the mean and standard deviation (SD) of market-adjusted short-run BHARs (in Panel A) and CARs (in Panel B) of 523 IPOs on the SHSE or SZSE over the period April 2001 to September 2008 across various issuing mechanisms: bookbuilding (BB; 271 IPOs); secondary market proportional offering (SMP; 208 IPOs); bookbuilding plus secondary market proportional offering (BS; 18 IPOs); and online fixed price offering (OFP; 26 IPOs).

The average annual number of trading days from 2001 to 2008 in the China stock market is 242 , so we define an event year as a 242-trading-day interval following the first day of listing, with an average of 20 trading days per month. We evaluate the marketadjusted BHARs and CARs up to 60 event days (three months) after listing.

Following the calculation introduced by Loughran and Ritter (1995), we define the market-adjusted $B H A R_{i, t}$ on IPO $i$ as: $B H A R_{i, t}=$ $\left[\prod_{t=1}^{T}\left(1+R_{i, t}\right)-1\right]-\left[\prod_{t=1}^{T}\left(1+R_{m, t}\right)-1\right]$, where $R_{i, t}$ and $R_{m, t}$ are the daily return on IPO $i$ and the corresponding market benchmark, respectively, in event day $t$ following listing. The SHSE or SZSE A-Share Index provides the benchmark for IPOs on the SHSE or SZSE, respectively. The mean buy-and-hold abnormal return $\overline{B H A R}_{t}$ on a portfolio of $N$ IPOs for a holding period of $t$ days is computed as: $\overline{B H A R}_{t}=\frac{1}{N_{t}} \sum_{i=1}^{N_{t}} B H A R_{i, t}$. To control for the potential skewness bias in the short-run returns, we use the bootstrapped skewness-adjusted $t$-statistics suggested by Lyon et al. (1999) to evaluate whethwe the BHAR is significantly different from zero: $t\left(\overline{B H A R}_{t}\right)=\sqrt{N_{t}}\left(S+\frac{1}{3} \hat{\gamma} S^{2}+\frac{1}{6 N_{t}} \hat{\gamma}\right)$, where: $S=\frac{\overline{B H A R}_{t}}{\sigma\left(B H A R_{t}\right)}$, and $\hat{\gamma}=\frac{\sum_{i=1}^{N_{t}}\left(B H A R_{i, t}-\overline{B H A R}_{t}\right)^{3}}{N_{t} \sigma\left(B H A R_{t}\right)^{3}}$, where $\hat{\gamma}$ is the estimate of the coefficient of skewness.

The market-adjusted return $A R_{i t}$ on firm $i$ in event day $t$ is defined as: $A R_{i, t}=R_{i, t}-R_{m, t}$. The mean market-adjusted return $A R_{t}$ on a portfolio of $N$ shares in event day $t$ is computed as: $A R_{t}=\frac{1}{N} \sum_{i=1}^{N} A R_{i, t}$. Therefore, the cumulative market-adjusted returns $C A R_{T}$ from event day 1 to event day $T$ are the summation of $A R_{t}: C A R_{T}=\sum_{t=1}^{T} A R_{t}$, while $t$-statistics of the $C A R_{T}$ are determined and computed using the methodology employed by Ritter (1991) as: $t\left(C A R_{T}\right)=C A R_{T} \times \sqrt{N} / c s d_{t}$, where $\operatorname{cs} d_{t}$ is computed as: $c s d_{t}=[t \times v a r+2 \times(t-1) \times c o v]^{1 / 2}$, where var is the mean cross-sectional variance over the 60 event days, and cov is the first-order autocovariance of the $A R_{t}$ series. 
Table 4 Regressions of mean market-adjusted initial returns and three-month BHARs on the firm-specific control variables, dummy variable of issuing mechanisms, various market return variables, and indicator variables, using a sample of 523 IPOs on the SHSE and SZSE

\begin{tabular}{|c|c|c|c|c|c|c|c|c|c|c|}
\hline & \multicolumn{5}{|c|}{ Mean of $I R$} & \multicolumn{5}{|c|}{ Mean of BHAR60 } \\
\hline & (1) & (2) & (3) & (4) & (5) & (6) & (7) & (8) & (9) & (10) \\
\hline INTERCEPT & $\begin{array}{r}0.7425 \\
(2.81)^{* * * *}\end{array}$ & $\begin{array}{r}0.7343 \\
(2.75)^{* * *}\end{array}$ & $\begin{array}{r}0.7126 \\
(2.63)^{* * *}\end{array}$ & $\begin{array}{r}0.7269 \\
(2.67)^{* * *}\end{array}$ & $\begin{array}{r}0.7238 \\
(2.65)^{* * * *}\end{array}$ & $\begin{array}{c}0.5260 \\
(2.39)^{* *}\end{array}$ & $\begin{array}{c}0.5251 \\
(2.34)^{* *}\end{array}$ & $\begin{array}{c}0.5167 \\
(2.29)^{* *}\end{array}$ & $\begin{array}{r}0.5129 \\
(2.25)^{* *}\end{array}$ & $\begin{array}{c}0.5185 \\
(2.32)^{* *}\end{array}$ \\
\hline LNSIZE & $\begin{array}{l}-0.4605 \\
(-2.44)^{* *}\end{array}$ & $\begin{array}{l}-0.4358 \\
(-2.41)^{* *}\end{array}$ & $\begin{array}{l}-0.4350 \\
(-2.36)^{* *}\end{array}$ & $\begin{array}{l}-0.4262 \\
(-2.31)^{* *}\end{array}$ & $\begin{array}{l}-0.4223 \\
(-2.30)^{* *}\end{array}$ & $\begin{array}{l}-0.2715 \\
(-2.26)^{* *}\end{array}$ & $\begin{array}{l}-0.2521 \\
(-2.25)^{* * *}\end{array}$ & $\begin{array}{l}-0.2431 \\
(-2.19)^{* *}\end{array}$ & $\begin{array}{l}-0.2122 \\
(-2.11)^{* *}\end{array}$ & $\begin{array}{l}-0.2135 \\
(-2.15)^{* *}\end{array}$ \\
\hline TECH & $\begin{array}{r}0.2021 \\
(1.47)\end{array}$ & $\begin{array}{r}0.1903 \\
(1.46)\end{array}$ & $\begin{array}{r}0.2055 \\
(1.50)\end{array}$ & $\begin{array}{r}0.1843 \\
(1.34)\end{array}$ & $\begin{array}{r}0.1877 \\
(1.45)\end{array}$ & $\begin{array}{r}0.2464 \\
(1.18)\end{array}$ & $\begin{array}{r}0.2474 \\
(1.23)\end{array}$ & $\begin{array}{r}0.2308 \\
(1.10)\end{array}$ & $\begin{array}{r}0.2438 \\
(1.15)\end{array}$ & $\begin{array}{r}0.2297 \\
(1.12)\end{array}$ \\
\hline$E X G$ & $\begin{array}{r}-0.1710 \\
(-1.28)\end{array}$ & $\begin{array}{r}-0.1674 \\
(-1.31)\end{array}$ & $\begin{array}{r}-0.1516 \\
(-1.36)\end{array}$ & $\begin{array}{r}-0.1790 \\
(-1.34)\end{array}$ & $\begin{array}{r}-0.1828 \\
(-1.38)\end{array}$ & $\begin{array}{r}-0.1583 \\
(-1.19)\end{array}$ & $\begin{array}{r}-0.1558 \\
(-1.22)\end{array}$ & $\begin{array}{r}-0.1389 \\
(-1.17)\end{array}$ & $\begin{array}{r}-0.1548 \\
(-1.20)\end{array}$ & $\begin{array}{r}-0.1519 \\
(-1.22)\end{array}$ \\
\hline STATE & $\begin{array}{l}-1.6972 \\
(-2.26)^{* *}\end{array}$ & $\begin{array}{l}-1.5322 \\
(-2.23)^{* *}\end{array}$ & $\begin{array}{l}-1.7095 \\
(-2.33)^{* *}\end{array}$ & $\begin{array}{l}-1.7015 \\
(-2.27)^{* *}\end{array}$ & $\begin{array}{l}-1.6307 \\
(-2.28)^{* *}\end{array}$ & $\begin{array}{l}-1.1639 \\
(-2.15)^{* *}\end{array}$ & $\begin{array}{l}-1.2343 \\
(-2.18)^{* *}\end{array}$ & $\begin{array}{l}-1.1775 \\
(-2.21)^{* *}\end{array}$ & $\begin{array}{l}-1.1438 \\
(-2.23)^{* *}\end{array}$ & $\begin{array}{l}-1.2124 \\
(-2.15)^{* *}\end{array}$ \\
\hline$R E G$ & $\begin{array}{l}0.2929 \\
(1.94)^{*}\end{array}$ & $\begin{array}{l}0.2662 \\
(1.89)^{*}\end{array}$ & $\begin{array}{l}0.2222 \\
(1.82)^{*}\end{array}$ & $\begin{array}{l}0.2517 \\
(1.87)^{*}\end{array}$ & $\begin{array}{l}0.2492 \\
(1.83)^{*}\end{array}$ & $\begin{array}{l}0.1812 \\
(1.73)^{*}\end{array}$ & $\begin{array}{l}0.1788 \\
(1.68)^{*}\end{array}$ & $\begin{array}{l}0.1617 \\
(1.67)^{*}\end{array}$ & $\begin{array}{l}0.1446 \\
(1.75)^{*}\end{array}$ & $\begin{array}{l}0.1324 \\
(1.74)^{*}\end{array}$ \\
\hline$B B$ & $\begin{array}{l}0.5870 \\
(2.37)^{* *}\end{array}$ & $\begin{array}{l}0.5355 \\
(2.22)^{* *}\end{array}$ & $\begin{array}{l}0.5090 \\
(2.14)^{* *}\end{array}$ & $\begin{array}{l}0.5011 \\
(2.16)^{* * *}\end{array}$ & $\begin{array}{l}0.4736 \\
(2.02)^{* *}\end{array}$ & $\begin{array}{l}0.4489 \\
(2.21)^{* *}\end{array}$ & $\begin{array}{l}0.4649 \\
(2.11)^{* *}\end{array}$ & $\begin{array}{l}0.4590 \\
(2.09)^{* *}\end{array}$ & $\begin{array}{l}0.4557 \\
(2.33)^{* * *}\end{array}$ & $\begin{array}{l}0.4201 \\
(2.01)^{* * *}\end{array}$ \\
\hline$B S$ & $\begin{array}{r}0.2824 \\
(1.58)\end{array}$ & $\begin{array}{r}0.2855 \\
(1.53)\end{array}$ & $\begin{array}{r}0.2884 \\
(1.45)\end{array}$ & $\begin{array}{r}0.2506 \\
(1.49)\end{array}$ & $\begin{array}{r}0.2593 \\
(1.51)\end{array}$ & $\begin{array}{r}0.2253 \\
(1.39)\end{array}$ & $\begin{array}{r}0.2384 \\
(1.46)\end{array}$ & $\begin{array}{r}0.2453 \\
(1.44)\end{array}$ & $\begin{array}{r}0.2245 \\
(1.41)\end{array}$ & $\begin{array}{r}0.2200 \\
(1.31)\end{array}$ \\
\hline$S M P$ & $\begin{array}{r}0.2626 \\
(1.40)\end{array}$ & $\begin{array}{r}0.2868 \\
(1.49)\end{array}$ & $\begin{array}{r}0.2558 \\
(1.42)\end{array}$ & $\begin{array}{r}0.2339 \\
(1.28)\end{array}$ & $\begin{array}{r}0.2405 \\
(1.33)\end{array}$ & $\begin{array}{r}0.2100 \\
(1.22)\end{array}$ & $\begin{array}{r}0.2294 \\
(1.36)\end{array}$ & $\begin{array}{r}0.2342 \\
(1.40)\end{array}$ & $\begin{array}{r}0.2124 \\
(1.34)\end{array}$ & $\begin{array}{r}0.2051 \\
(1.28)\end{array}$ \\
\hline MktRet_1w & & $\begin{array}{r}3.1135 \\
(3.98)^{* * *}\end{array}$ & & & & & $\begin{array}{r}3.4225 \\
(4.33)^{* * * *}\end{array}$ & & & \\
\hline MktRet_Im & & & $\begin{array}{r}2.9034 \\
(4.18)^{* * *}\end{array}$ & & & & & $\begin{array}{r}3.2303 \\
(4.45)^{* * *}\end{array}$ & & \\
\hline MktRet_3m & & & & $\begin{array}{r}2.9547 \\
(3.94)^{* * *}\end{array}$ & & & & & $\begin{array}{r}3.4078 \\
(4.28)^{* * * *}\end{array}$ & \\
\hline MktRet_3w & & & & & $\begin{array}{r}3.0158 \\
(4.17)^{* * * *}\end{array}$ & & & & & $\begin{array}{r}3.4561 \\
(4.40)^{* * *}\end{array}$ \\
\hline YEAR & YES & YES & YES & YES & YES & YES & YES & YES & YES & YES \\
\hline INDUSTRY & YES & YES & YES & YES & YES & YES & YES & YES & YES & YES \\
\hline $\operatorname{Adj} . R^{2}$ & 0.0637 & 0.2867 & 0.2587 & 0.2586 & 0.2631 & 0.0562 & 0.2402 & 0.2478 & 0.2558 & 0.2417 \\
\hline
\end{tabular}

This table presents the results of cross-sectional OLS regressions explaining the mean market-adjusted initial returns $(I R)$ and threemonth BHARs (BHAR60) with the use of 523 IPOs on the SHSE or SZSE over the period April 2001 to September 2008. IR of each IPO on the SHSE or SZSE is measured by the percentage difference between the first trading day closing price and offering price, relative to the contemporaneous return on the SHSE or SZSE A-Share Index, respectively. BHAR60 is measured as the market-adjusted three-month BHR as shown in Table 3. The regression model is presented as follows:

$$
\begin{gathered}
I R \text { or BHAR60 }=\beta_{0}+\beta_{1} L N S I Z E+\beta_{2} T E C H+\beta_{3} E X G+\beta_{4} F L O A T+\beta_{5} R E G+\beta_{6} B B+\beta_{7} B S+\beta_{8} S M P \\
+\beta_{9}[\text { Market Return Variable }]+Y E A R+I N D U S T R Y+\varepsilon,
\end{gathered}
$$

where $L N S I Z E$ represents the natural logarithm of the raised aggregate gross proceeds of the IPO firm in millions of RMB, adjusted using CPI $(2005=100)$; TECH is a dummy variable set to one if the IPO firm has some high-tech related contents, according to the ICB, and zero otherwise (see the distribution of all IPOs in our sample by the industry category in Appendix); EXG is a dummy variable set to one if the IPO firm is listed on the SHSE, and zero otherwise; STATE represents the fraction of tradable shares by total shares outstanding of the IPO firm; $R E G$ is a dummy variable set to one if the IPO firm issues new shares after January 1st, 2005 when The Regulation 2004 was applicable, and zero otherwise; and $B B, B S$, and $S M P$ represent bookbuilding (BB; 271 IPOs), bookbuilding plus secondary market proportional offering (BS; 18 IPOs), and secondary market proportional offering (SMP; 208 IPOs), respectively. The intercept term captures the effect of online fixed price offering (OFP; 26 IPOs). For each IPO on the SHSE or SZSE, the market return variables are constructed for the one-week (MktRet_lw), one-month (MktRet_lm), and three-month $($ MktRet_3m) periods before the offering date as the BHR on the SHSE or SZSE A-Share Index, respectively. The three-month weighted market return variable (MktRet_3w) is constructed as a weighted average BHR of the corresponding market index return in three months prior to offering. The weights are three for the most recent month, two for the next, and one for the third month prior to offering (Derrien and Womack, 2003). We also control for the potential year and industry fixed effects using indicator variables for years (YEAR) and industries (INDUSTRY), according to the two-digit ICB codes. White heteroscedasticity-consistent $t$-statistics are reported in parenthesis. ${ }^{*},{ }^{* *}$, and ${ }^{* * *}$ denote statistical significance at the 10,5 , and $1 \%$ levels, respectively. 
Table 5 Regressions of mean and squared deviation of market-adjusted initial returns and three-month BHARs on the firm-specific control variables, dummy variables of issuing mechanisms, market return and volatility variables, interaction variables, and indicator variables, using a sample of 523 IPOs on the SHSE and SZSE

\begin{tabular}{|c|c|c|c|c|c|c|c|c|}
\hline & \multicolumn{2}{|c|}{ Mean of $I R$} & \multicolumn{2}{|c|}{ Mean of BHAR6O } & \multicolumn{2}{|c|}{ Squared deviation of $I R$} & \multicolumn{2}{|c|}{ Squared deviation of $B H A R 60$} \\
\hline & (11) & (12) & (13) & (14) & (15) & (16) & (17) & (18) \\
\hline INTERCEPT & $\begin{array}{c}0.5923 \\
(2.46)^{* * *}\end{array}$ & $\begin{array}{c}0.5845 \\
(2.44)^{* *}\end{array}$ & $\begin{array}{c}0.4189 \\
(2.15)^{* *}\end{array}$ & $\begin{array}{c}0.4357 \\
(2.06)^{* *}\end{array}$ & $\begin{array}{r}0.1557 \\
(1.38)\end{array}$ & $\begin{array}{r}0.1480 \\
(1.34)\end{array}$ & $\begin{array}{r}0.1317 \\
(1.22)\end{array}$ & $\begin{array}{r}0.1282 \\
(1.19)\end{array}$ \\
\hline LNSIZE & $\begin{array}{l}-0.4106 \\
(-2.44)^{* *}\end{array}$ & $\begin{array}{l}-0.4154 \\
(-2.47)^{* *}\end{array}$ & $\begin{array}{l}-0.3150 \\
(-2.19)^{* *}\end{array}$ & $\begin{array}{l}-0.3552 \\
(-2.35)^{* *}\end{array}$ & $\begin{array}{l}-0.1072 \\
(-1.75)^{*}\end{array}$ & $\begin{array}{l}-0.1120 \\
(-1.87)^{*}\end{array}$ & $\begin{array}{l}-0.0880 \\
(-1.72)^{*}\end{array}$ & $\begin{array}{l}-0.0836 \\
(-1.73)^{*}\end{array}$ \\
\hline TECH & $\begin{array}{r}0.1281 \\
(1.12)\end{array}$ & $\begin{array}{r}0.1290 \\
(1.14)\end{array}$ & $\begin{array}{r}0.1496 \\
(1.34)\end{array}$ & $\begin{array}{r}0.1543 \\
(1.36)\end{array}$ & $\begin{array}{r}0.0901 \\
(0.74)\end{array}$ & $\begin{array}{r}0.0805 \\
(0.68)\end{array}$ & $\begin{array}{r}0.0564 \\
(0.64)\end{array}$ & $\begin{array}{r}0.0535 \\
(0.60)\end{array}$ \\
\hline$E X G$ & $\begin{array}{r}-0.1947 \\
(-1.50)\end{array}$ & $\begin{array}{r}-0.2134 \\
(-1.49)\end{array}$ & $\begin{array}{r}-0.1555 \\
(-1.23)\end{array}$ & $\begin{array}{r}-0.1651 \\
(-1.32)\end{array}$ & $\begin{array}{r}-0.1279 \\
(-1.02)\end{array}$ & $\begin{array}{r}-0.1306 \\
(-1.06)\end{array}$ & $\begin{array}{r}-0.1406 \\
(-1.11)\end{array}$ & $\begin{array}{r}-0.1410 \\
(-1.13)\end{array}$ \\
\hline STATE & $\begin{array}{l}-0.9467 \\
(-2.01)^{* *}\end{array}$ & $\begin{array}{l}-1.0377 \\
(-2.14)^{* *}\end{array}$ & $\begin{array}{l}-1.4367 \\
(-2.35)^{* *}\end{array}$ & $\begin{array}{l}-1.4183 \\
(-2.09)^{* *}\end{array}$ & $\begin{array}{l}-0.0981 \\
(-1.80)^{*}\end{array}$ & $\begin{array}{l}-0.1017 \\
(-1.91)^{*}\end{array}$ & $\begin{array}{l}-0.0594 \\
(-1.74)^{*}\end{array}$ & $\begin{array}{l}-0.0484 \\
(-1.70)^{*}\end{array}$ \\
\hline$R E G$ & $\begin{array}{l}0.2306 \\
(1.92)^{*}\end{array}$ & $\begin{array}{l}0.2129 \\
(1.85)^{*}\end{array}$ & $\begin{array}{l}0.1623 \\
(1.68)^{*}\end{array}$ & $\begin{array}{l}0.1728 \\
(1.71)^{*}\end{array}$ & $\begin{array}{l}0.0577 \\
(1.81)^{*}\end{array}$ & $\begin{array}{l}0.0558 \\
(1.79)^{*}\end{array}$ & $\begin{array}{l}0.0434 \\
(1.70)^{*}\end{array}$ & $\begin{array}{l}0.0427 \\
(1.68)^{*}\end{array}$ \\
\hline$B B$ & $\begin{array}{l}0.6447 \\
(2.22)^{* *}\end{array}$ & $\begin{array}{l}0.6830 \\
(2.35)^{* *}\end{array}$ & $\begin{array}{l}0.5800 \\
(2.14)^{* * *}\end{array}$ & $\begin{array}{l}0.5518 \\
(2.05)^{* *}\end{array}$ & $\begin{array}{l}0.1514 \\
(2.05)^{* *}\end{array}$ & $\begin{array}{l}0.1554 \\
(2.13)^{* *}\end{array}$ & $\begin{array}{l}0.1198 \\
(2.27)^{* * *}\end{array}$ & $\begin{array}{r}0.1084 \\
(2.11)^{* * *}\end{array}$ \\
\hline$B S$ & $\begin{array}{r}0.2415 \\
(1.29)\end{array}$ & $\begin{array}{r}0.2340 \\
(1.24)\end{array}$ & $\begin{array}{r}0.2214 \\
(1.38)\end{array}$ & $\begin{array}{r}0.2219 \\
(1.41)\end{array}$ & $\begin{array}{r}0.1210 \\
(0.76)\end{array}$ & $\begin{array}{r}0.1258 \\
(0.85)\end{array}$ & $\begin{array}{r}0.0752 \\
(0.60)\end{array}$ & $\begin{array}{r}0.0672 \\
(0.52)\end{array}$ \\
\hline$S M P$ & $\begin{array}{r}0.2316 \\
(1.23)\end{array}$ & $\begin{array}{r}0.2233 \\
(1.19)\end{array}$ & $\begin{array}{r}0.2095 \\
(1.31)\end{array}$ & $\begin{array}{r}0.2061 \\
(1.27)\end{array}$ & $\begin{array}{r}0.1054 \\
(0.70)\end{array}$ & $\begin{array}{r}0.1109 \\
(0.79)\end{array}$ & $\begin{array}{r}0.0619 \\
(0.47)\end{array}$ & $\begin{array}{r}0.0558 \\
(0.46)\end{array}$ \\
\hline MktRet_3w & $\begin{array}{r}4.0523 \\
(3.53)^{* * * *}\end{array}$ & & $\begin{array}{r}4.3894 \\
(3.88)^{* * *}\end{array}$ & & $\begin{array}{r}2.1487 \\
(2.84)^{* * *}\end{array}$ & & $\begin{array}{c}2.1923 \\
(2.97)^{* * *}\end{array}$ & \\
\hline MktRet_3w $\times B B$ & & $\begin{array}{l}4.1027 \\
(2.92)^{* * * *}\end{array}$ & & $\begin{array}{r}3.9283 \\
(2.82)^{* * *}\end{array}$ & & $\begin{array}{l}1.7161 \\
(2.21)^{* *}\end{array}$ & & $\begin{array}{r}1.5134 \\
(2.02)^{* *}\end{array}$ \\
\hline MktRet_3w $\times B S$ & & $\begin{array}{r}1.6762 \\
(1.57)\end{array}$ & & $\begin{array}{r}1.4379 \\
(1.45)\end{array}$ & & $\begin{array}{r}0.2559 \\
(0.59)\end{array}$ & & $\begin{array}{r}0.2343 \\
(0.46)\end{array}$ \\
\hline MktRet_3w $\times$ OFP & & $\begin{array}{l}3.7052 \\
(2.42)^{* *}\end{array}$ & & $\begin{array}{l}3.5651 \\
(2.31)^{* *}\end{array}$ & & $\begin{array}{l}0.6629 \\
(2.09)^{* * *}\end{array}$ & & $\begin{array}{l}0.5768 \\
(2.03)^{* *}\end{array}$ \\
\hline MktRet_3w $\times S M P$ & & $\begin{array}{r}1.5463 \\
(1.52)\end{array}$ & & $\begin{array}{r}1.3108 \\
(1.41)\end{array}$ & & $\begin{array}{r}0.2345 \\
(0.27)\end{array}$ & & $\begin{array}{r}0.2106 \\
(0.24)\end{array}$ \\
\hline MktVol_lm & $\begin{array}{r}3.8488 \\
(2.67)^{* * * *}\end{array}$ & & $\begin{array}{c}3.8161 \\
(2.61)^{* * *}\end{array}$ & & $\begin{array}{l}1.7250 \\
(2.40)^{* *}\end{array}$ & & $\begin{array}{l}1.6267 \\
(2.35)^{* *}\end{array}$ & \\
\hline MktVol_lm $\times B B$ & & $\begin{array}{r}3.89999 \\
(2.98)^{* * * *}\end{array}$ & & $\begin{array}{r}3.4106 \\
(2.84)^{* * *}\end{array}$ & & $\begin{array}{r}1.5563 \\
(2.80)^{* * *}\end{array}$ & & $\begin{array}{r}1.4717 \\
(2.72)^{* * *}\end{array}$ \\
\hline MktVol_lm $\times B S$ & & $\begin{array}{r}2.1316 \\
(1.56)\end{array}$ & & $\begin{array}{r}2.1102 \\
(1.32)\end{array}$ & & $\begin{array}{r}0.1992 \\
(0.84)\end{array}$ & & $\begin{array}{r}0.1913 \\
(0.95)\end{array}$ \\
\hline MktVol_lm $\times$ OFP & & $\begin{array}{l}2.2058 \\
(2.04)^{* * *}\end{array}$ & & $\begin{array}{l}2.2385 \\
(2.14)^{* *}\end{array}$ & & $\begin{array}{l}0.9038 \\
(1.85)^{*}\end{array}$ & & $\begin{array}{l}0.8660 \\
(1.71)^{*}\end{array}$ \\
\hline MktVol_1m $\times S M P$ & & $\begin{array}{r}1.8954 \\
(1.28)\end{array}$ & & $\begin{array}{r}1.8383 \\
(1.20)\end{array}$ & & $\begin{array}{r}0.1574 \\
(0.69)\end{array}$ & & $\begin{array}{r}0.1633 \\
(0.84)\end{array}$ \\
\hline$Y E A R$ & YES & YES & YES & YES & YES & YES & YES & YES \\
\hline INDUSTRY & YES & YES & YES & YES & YES & YES & YES & YES \\
\hline $\operatorname{Adj} . R^{2}$ & 0.2951 & 0.3109 & 0.3039 & 0.3223 & 0.2196 & 0.2357 & 0.2246 & 0.2358 \\
\hline
\end{tabular}

This table presents the results of cross-sectional OLS regressions explaining the mean and squared deviation of market-adjusted initial returns (IR) and three-month BHARs (BHAR60) with the use of 523 IPOs on the SHSE or SZSE over the period April 2001 to September 2008. IR of each IPO on the SHSE or SZSE is measured by the percentage difference between the first trading day closing price and offering price, relative to the contemporaneous return on the SHSE or SZSE A-Share Index, respectively. BHAR60 is measured as the market-adjusted three-month BHR as shown in Table 3. The squared deviations of IR and BHAR60 employed in Regressions (15-18) are constructed as the squared residuals from Regressions (11-14), respectively. The regression model is presented as follows:

$$
\begin{aligned}
I R \text { or BHAR60 }= & \beta_{0}+\beta_{1} L N S I Z E+\beta_{2} T E C H+\beta_{3} E X G+\beta_{4} F L O A T+\beta_{5} R E G+\beta_{6} B B+\beta_{7} B S+\beta_{8} S M P+\beta_{9} M k t R e t \_3 w \\
& +\beta_{10} M k t R e t_{-} 3 w \times B B+\beta_{11} M k t R e t \_3 w \times B S+\beta_{12} M k t R e t \_3 w \times O F P+\beta_{13} M k t M k t \_3 w \times S M P \\
& +\beta_{14} M k t V o l \_1 m+\beta_{15} M k t V o l \_1 m \times B B+\beta_{16} M k t V o l \_1 m \times B S+\beta_{17} M k t V o l \_1 m \times O F P \\
& +\beta_{18} M k t V o l \_1 m \times S M P+Y E A R+I N D U S T R Y+\varepsilon
\end{aligned}
$$

where the firm-specific control variables of $L N S I Z E, T E C H, E X G, S T A T E$, and REG, dummy variables of issuing mechanisms of $B B, B S$, and $S M P$, market condition variables of $M k t R e t \_3 w$ and $M k t V o l \_l m$, and indicator variables of YEAR and INDUSTRY are as defined in Table 4. The intercept term captures the effect of online fixed price offering $(O F P)$. The interaction variables of $M k t R e t \_3 w \times B B, M k t R e t \_3 w \times B S, M k t R e t \_3 w \times O F P$, and MktRet_3w $\times S M P$ represent the products of market return with each issuing mechanism; the interaction variables of $M k t V o l \_1 m \times B B, M k t V o l \_1 m \times B S, M k t V o l \_1 m \times O F P$, and MktVol_lm $\times$ SMP represent the products of market volatility with each issuing mechanism. White heteroscedasticity-consistent $t$-statistics are reported in parenthesis. ${ }^{*}, * *$, and ${ }^{* * *}$ denote statistical significance at the 10,5 , and $1 \%$ levels, respectively. 
Table 6 Two-stage Heckman (1979) results, using a sample of 479 IPOs on the SHSE and SZSE

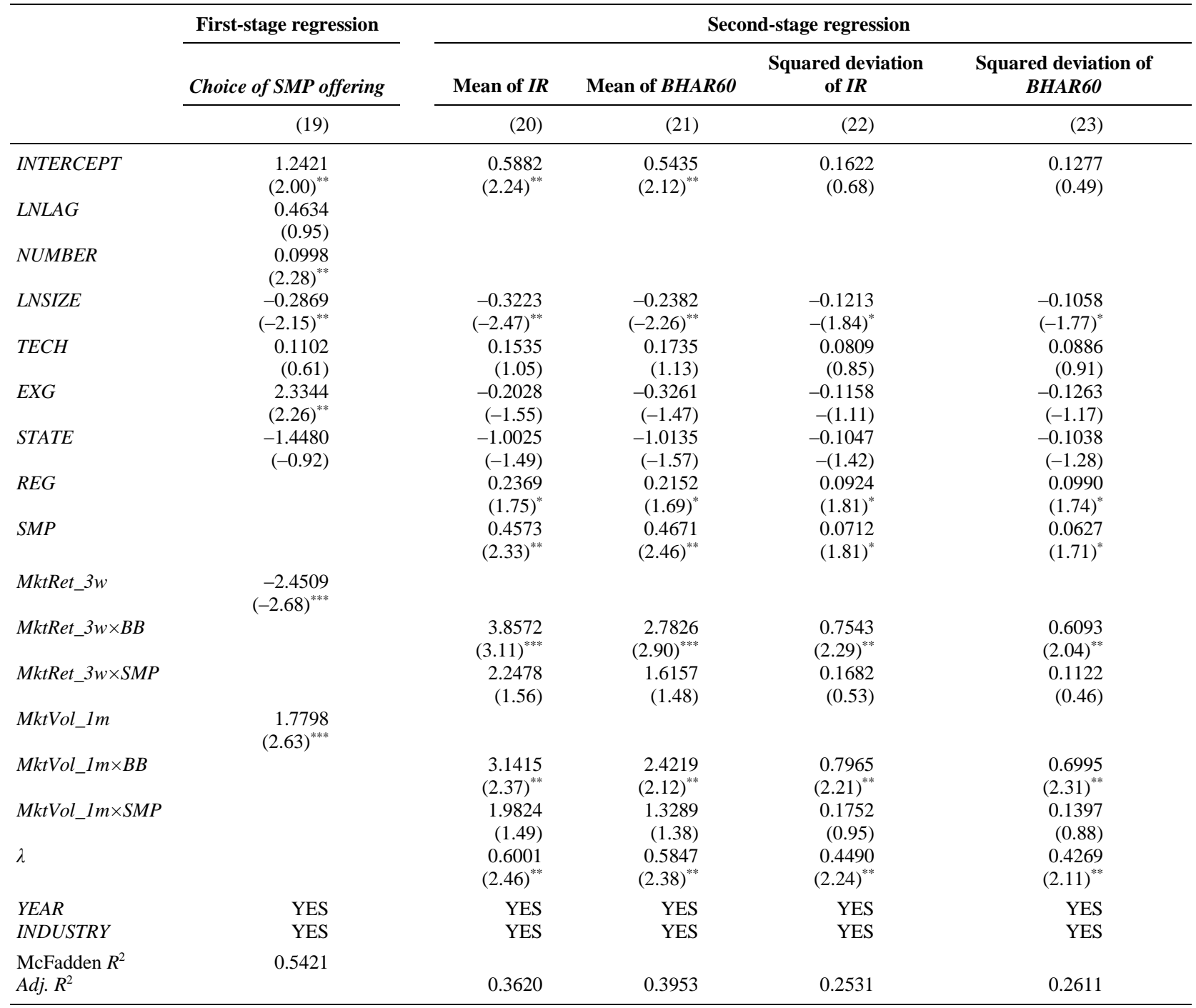

This table presents the Heckman (1979) two-stage results on the mean and squared deviation of market-adjusted initial returns $(I R)$ and three-month BHARs (BHAR60) with the use of 479 IPOs on the SHSE and SZSE over the period April 2001 to September 2008. In the first-stage regression, we use a probit model to estimate the probability that an issuer tends to choose SMP offering:

$$
\begin{gathered}
\text { Probability of choosing SMP offering }=\alpha_{0}+\alpha_{1} L N L A G+\alpha_{2} N U M B E R+\alpha_{3} L N S I Z E+\alpha_{4} T E C H+\alpha_{5} E X G+ \\
\alpha_{6} \text { FLOAT }+\alpha_{7} \text { MktRet_3w }+\alpha_{8} M k t V o l \_1 m+Y E A R+I N D U S T R Y+\xi,
\end{gathered}
$$

where the dependent variable is a binary dummy variable set to one if the issuer chooses SMP offering, and zero otherwise; $L N L A G$ represents the natural logarithm of the number of days between the offering and listing dates; NUMBER represents the number of IPOs issued during the six weeks before to two weeks after the issuer's offering date; the firm-specific control variables of $L N S I Z E$, $T E C H, E X G$, and STATE, market condition variables of MktRet_3w and MktVol_lm, and indicator variables of YEAR and INDUSTRY are as defined in Table 4.

The second-stage OLS regression includes the inverse Mills ratio $(\lambda)$ derived from the first-stage regression as an additional regressor to correct for the self-selection bias. Specifically, $\lambda_{i}=\phi\left(\gamma Z_{i}\right) /\left[1-\Phi\left(\gamma Z_{i}\right)\right]$, where $\phi$ represents the standard normal density function; $\Phi$ represents the standard normal cumulative distribution function; $\gamma$ represents the first-stage probit estimation of the selection equation; $Z$ represents the corresponding explanatory variables in the probit regression. IR of each IPO on the SHSE or SZSE is measured by the percentage difference between the first trading day closing price and offering price, relative to the contemporaneous return on the SHSE or SZSE A-Share Index, respectively. BHAR60 is measured as the market-adjusted threemonth BHR as shown in Table 3. The squared deviations of IR and BHAR60 employed in Regressions (22-23) are constructed as the squared residuals from Regressions (20-21), respectively. The second-stage regression model is presented as follows:

$$
\begin{aligned}
& \text { IR or BHAR } 60=\beta_{0}+\beta_{1} L N S I Z E+\beta_{2} T E C H+\beta_{3} E X G+\beta_{4} F L O A T+\beta_{5} R E G+\beta_{6} S M+\beta_{7} M k t R e t \_3 w \times B B \\
& +\beta_{8} M k t R e t \_3 w \times S M+\beta_{9} M k t V o l \_1 m \times B B+\beta_{10} M k t V o l \_1 m \times S M+\beta_{11} \lambda+Y E A R+I N D U S T R Y \\
& +\varepsilon,
\end{aligned}
$$

where the firm-specific control variables of LNSIZE, TECH, EXG, STATE, and REG, dummy variable of issuing mechanism of $S M P$, and indicator variables of YEAR and INDUSTRY are as defined in Table 4. The intercept term captures the effect of bookbuilding $(B B)$. The interaction variables of MktRet_3w $\times B B, M k t R e t \_3 w \times S M P, M k t V o l \_1 m \times B B$, and $M k t V o l \_1 m \times S M P$ are as defined in Table 5. White heteroscedasticity-consistent $t$-statistics are reported in parenthesis. ${ }^{*},{ }^{* *}$, and ${ }^{* * *}$ denote statistical significance at the 10,5 , and $1 \%$ levels, respectively. 
Table 7 Regressions of mean and squared deviation of market-adjusted initial returns and three-month BHARs on the firm-specific control variables, dummy variables of issuing mechanisms, market return and volatility variables, interaction variables, and indicator variables, using a sample of 343 IPOs on the SHSE

\begin{tabular}{|c|c|c|c|c|c|c|c|c|}
\hline & \multicolumn{2}{|c|}{ Mean of $I R$} & \multicolumn{2}{|c|}{ Mean of BHAR6O } & \multicolumn{2}{|c|}{ Squared deviation of $I R$} & \multicolumn{2}{|c|}{ Squared deviation of BHAR6O } \\
\hline & (24) & (25) & (26) & (27) & (28) & (29) & (30) & (31) \\
\hline INTERCEPT & $\begin{array}{c}0.4526 \\
(2.36)^{* * *}\end{array}$ & $\begin{array}{c}0.5059 \\
(2.28)^{* *}\end{array}$ & $\begin{array}{c}0.3837 \\
(2.17)^{* *}\end{array}$ & $\begin{array}{c}0.3681 \\
(2.09)^{* * *}\end{array}$ & $\begin{array}{r}0.1384 \\
(1.13)\end{array}$ & $\begin{array}{r}0.1242 \\
(1.15)\end{array}$ & $\begin{array}{r}0.1332 \\
(1.26)\end{array}$ & $\begin{array}{r}0.1068 \\
(1.24)\end{array}$ \\
\hline LNSIZE & $\begin{array}{l}-0.3372 \\
(-2.03)^{* *}\end{array}$ & $\begin{array}{l}-0.3630 \\
(-2.05)^{* * *}\end{array}$ & $\begin{array}{l}-0.2231 \\
(-1.90)^{*}\end{array}$ & $\begin{array}{l}-0.2434 \\
(-1.86)^{*}\end{array}$ & $\begin{array}{l}-0.0760 \\
(-1.83)^{*}\end{array}$ & $\begin{array}{l}-0.0881 \\
(-1.81)^{*}\end{array}$ & $\begin{array}{l}-0.0602 \\
(-1.76)^{*}\end{array}$ & $\begin{array}{l}-0.0653 \\
(-1.85)^{*}\end{array}$ \\
\hline TECH & $\begin{array}{r}-0.1208 \\
(-1.35)\end{array}$ & $\begin{array}{r}-0.1388 \\
(-1.45)\end{array}$ & $\begin{array}{r}-0.1642 \\
(-1.56)\end{array}$ & $\begin{array}{r}-0.1785 \\
(-1.59)\end{array}$ & $\begin{array}{r}-0.0795 \\
(-0.69)\end{array}$ & $\begin{array}{r}-0.0798 \\
(-0.71)\end{array}$ & $\begin{array}{r}-0.0642 \\
(-0.52)\end{array}$ & $\begin{array}{r}-0.0624 \\
(-0.47)\end{array}$ \\
\hline STATE & $\begin{array}{r}-0.6647 \\
(-0.55)\end{array}$ & $\begin{array}{r}-0.6933 \\
(-0.52)\end{array}$ & $\begin{array}{r}-0.6077 \\
(-0.73)\end{array}$ & $\begin{array}{r}-0.5126 \\
(-0.75)\end{array}$ & $\begin{array}{r}-0.0521 \\
(-1.08)\end{array}$ & $\begin{array}{r}-0.0538 \\
(-1.07)\end{array}$ & $\begin{array}{r}-0.0393 \\
(-1.15)\end{array}$ & $\begin{array}{r}-0.0341 \\
(-1.02)\end{array}$ \\
\hline$R E G$ & $\begin{array}{l}0.2096 \\
(1.76)^{*}\end{array}$ & $\begin{array}{l}0.2159 \\
(1.83)^{*}\end{array}$ & $\begin{array}{l}0.1761 \\
(1.74)^{*}\end{array}$ & $\begin{array}{l}0.1720 \\
(1.67)^{*}\end{array}$ & $\begin{array}{l}0.0621 \\
(1.91)^{*}\end{array}$ & $\begin{array}{l}0.0559 \\
(1.74)^{*}\end{array}$ & $\begin{array}{l}0.0363 \\
(1.67)^{*}\end{array}$ & $\begin{array}{l}0.0376 \\
(1.74)^{*}\end{array}$ \\
\hline$B B$ & $\begin{array}{l}0.6769 \\
(2.14)^{* *}\end{array}$ & $\begin{array}{l}0.6067 \\
(2.03)^{* *}\end{array}$ & $\begin{array}{l}0.4496 \\
(2.21)^{* *}\end{array}$ & $\begin{array}{l}0.5357 \\
(2.24)^{* *}\end{array}$ & $\begin{array}{l}0.1283 \\
(2.03)^{* *}\end{array}$ & $\begin{array}{l}0.1321 \\
(2.09)^{* *}\end{array}$ & $\begin{array}{l}0.0870 \\
(2.06)^{* *}\end{array}$ & $\begin{array}{l}0.0858 \\
(2.00)^{* * *}\end{array}$ \\
\hline$S M P$ & $\begin{array}{r}0.4740 \\
(1.50)\end{array}$ & $\begin{array}{r}0.4910 \\
(1.40)\end{array}$ & $\begin{array}{r}0.3185 \\
(1.44)\end{array}$ & $\begin{array}{r}0.3820 \\
(1.29)\end{array}$ & $\begin{array}{r}0.2149 \\
(1.32)\end{array}$ & $\begin{array}{r}0.2812 \\
(1.13)\end{array}$ & $\begin{array}{r}0.1741 \\
(0.88)\end{array}$ & $\begin{array}{r}0.1718 \\
(0.76)\end{array}$ \\
\hline$M k t R e t \_3 w$ & $\begin{array}{r}2.7330 \\
(3.06)^{* * *}\end{array}$ & & $\begin{array}{r}2.8768 \\
(3.27)^{* * *}\end{array}$ & & $\begin{array}{l}1.7392 \\
(2.51)^{* * *}\end{array}$ & & $\begin{array}{l}1.5682 \\
(2.37)^{* * *}\end{array}$ & \\
\hline MktRet_3w $\times B B$ & & $\begin{array}{c}3.3460 \\
(2.31)^{* *}\end{array}$ & & $\begin{array}{c}3.0323 \\
(2.20)^{* *}\end{array}$ & & $\begin{array}{c}1.8109 \\
(2.14)^{* * *}\end{array}$ & & $\begin{array}{l}1.8718 \\
(2.08)^{* *}\end{array}$ \\
\hline MktRet_3w $\times$ OFP & & $\begin{array}{l}2.3103 \\
(2.11)^{* *}\end{array}$ & & $\begin{array}{l}2.1991 \\
(2.03)^{* *}\end{array}$ & & $\begin{array}{l}1.4399 \\
(1.81)^{*}\end{array}$ & & $\begin{array}{l}1.3474 \\
(1.75)^{*}\end{array}$ \\
\hline MktRet_3w $\times S M P$ & & $\begin{array}{r}1.7107 \\
(1.55)\end{array}$ & & $\begin{array}{r}1.4767 \\
(1.45)\end{array}$ & & $\begin{array}{r}0.3266 \\
(0.95)\end{array}$ & & $\begin{array}{r}0.2791 \\
(0.86)\end{array}$ \\
\hline MktVol_lm & $\begin{array}{c}3.4287 \\
(2.42)^{* *}\end{array}$ & & $\begin{array}{r}3.2494 \\
(2.16)^{* *}\end{array}$ & & $\begin{array}{c}2.0199 \\
(2.30)^{* *}\end{array}$ & & $\begin{array}{c}1.8222 \\
(2.20)^{* *}\end{array}$ & \\
\hline MktVol_lm $\times B B$ & & $\begin{array}{r}3.3202 \\
(2.75)^{* * *}\end{array}$ & & $\begin{array}{r}2.6959 \\
(2.62)^{* * *}\end{array}$ & & $\begin{array}{c}0.9888 \\
(2.43)^{* *}\end{array}$ & & $\begin{array}{l}0.8733 \\
(2.39)^{* *}\end{array}$ \\
\hline MktVol_lm $\times$ OFP & & $\begin{array}{l}2.5552 \\
(2.37)^{* *}\end{array}$ & & $\begin{array}{l}2.3275 \\
(2.22)^{* *}\end{array}$ & & $\begin{array}{l}0.6018 \\
(1.77)^{*}\end{array}$ & & $\begin{array}{l}0.4568 \\
(1.68)^{*}\end{array}$ \\
\hline MktVol_1m $\times S M P$ & & $\begin{array}{r}1.6884 \\
(1.55)\end{array}$ & & $\begin{array}{r}1.5548 \\
(1.49)\end{array}$ & & $\begin{array}{r}0.1955 \\
(1.29)\end{array}$ & & $\begin{array}{r}0.1707 \\
(1.02)\end{array}$ \\
\hline$Y E A R$ & YES & YES & YES & YES & YES & YES & YES & YES \\
\hline INDUSTRY & YES & YES & YES & YES & YES & YES & YES & YES \\
\hline $\operatorname{Adj} . R^{2}$ & 0.3466 & 0.3897 & 0.2929 & 0.3209 & 0.2065 & 0.2329 & 0.2203 & 0.2509 \\
\hline
\end{tabular}

This table presents the results of cross-sectional OLS regressions explaining the mean and squared deviation of market-adjusted initial returns (IR) and three-month BHARs (BHAR60) with the use of 343 IPOs on the SHSE over the period April 2001 to October 2012. A total of three IPOs using bookbuilding plus secondary market proportional offering (BS) are excluded in the regression analysis due to the very limited sample. $I R$ of each IPO on the SHSE or SZSE is measured by the percentage difference between the first trading day closing price and offering price, relative to the contemporaneous return on the SHSE or SZSE A-Share Index, respectively. BHAR60 is measured as the market-adjusted three-month BHR as shown in Table 3. The squared deviations of IR and BHAR60 employed in Regressions (28-31) are constructed as the squared residuals from Regressions (24-27), respectively. The regression model is presented as follows:

IR or BHAR60 $=\beta_{0}+\beta_{1} L N S I Z E+\beta_{2}$ TECH $+\beta_{3} F L O A T+\beta_{4} B B+\beta_{5} S M P+\beta_{6} M k t R e t_{-} 3 w+\beta_{7} M k t R e t \_3 w \times B B+\beta_{8} M k t R e t \_3 w$ $\times O F P+\beta_{9} M k t R e t \_3 w \times S M P+\beta_{10} M k t V o l \_1 m+\beta_{11} M k t V o l \_1 m \times B B+\beta_{12} M k t V o l \_1 m \times O F P+\beta_{13} M k t V o l \_1 m$ $\times S M P+Y E A R+I N D U S T R Y+\varepsilon$,

where the firm-specific control variables of LNSIZE, TECH, EXG, STATE, REG; dummy variables of issuing mechanisms of $B B$ and $S M P$, market condition variables of $M k t R e t \_3 w$ and $M k t V o l \_l m$, and indicator variables of YEAR and INDUSTRY are as defined in Table 4. The intercept term captures the effect of online fixed price offering $(O F P)$. The interaction variables of $M k t R e t \_3 w \times B B$,

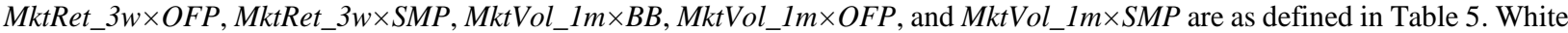
heteroscedasticity-consistent $t$-statistics are reported in parenthesis. ${ }^{*},{ }^{* *}$, and ${ }^{* * *}$ denote statistical significance at the 10,5 , and $1 \%$ levels, respectively. 


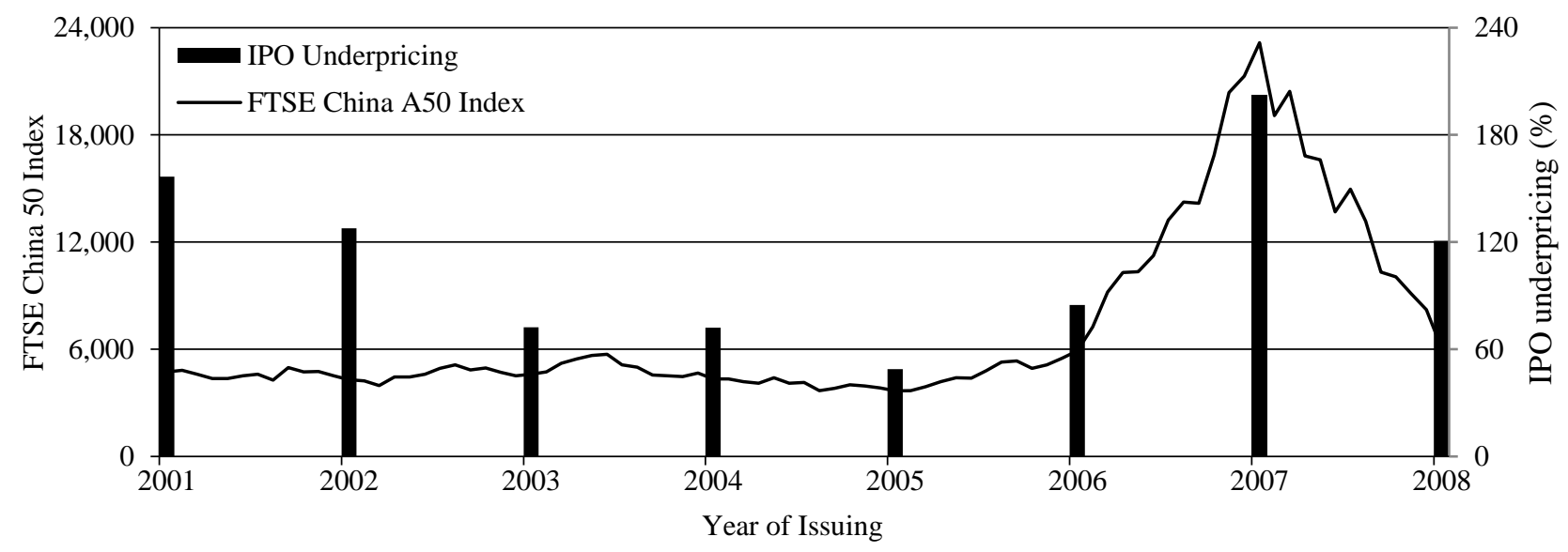

Figure 1 IPO underpricing and market performance in the China stock market over the period 2001 to 2008

The level of IPO underpricing is measured as the adjusted average initial return, the percentage difference between the first trading day closing price and offering price, relative to the contemporaneous return on the SHSE or SZSE A-Share Index, respectively. The FTSE China A50 Index is a real-time, tradable index comprising the largest 50 A-Shares listed on the SHSE and SZSE by full market capitalization, which offers the optimal balance between representativeness and tradability for the China A-Share market. 


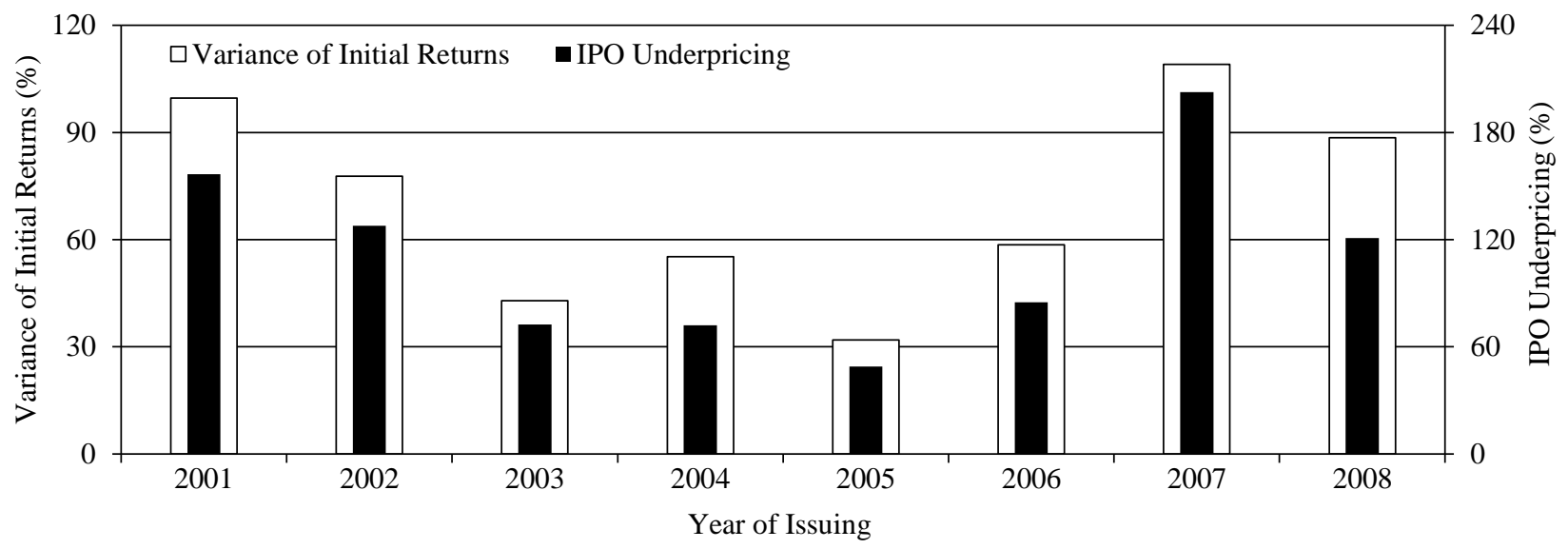

Figure 2 IPO underpricing and variance of initial returns of IPOs in the China stock market over the period 2001 to 2008

The level of IPO underpricing is measured as the adjusted average initial return, the percentage difference between the first trading day closing price and offering price, relative to the contemporaneous return on the SHSE or SZSE A-Share Index, respectively. The variance of initial returns is measured as the cross-sectional standard deviation of initial returns of IPOs. 